NBER WORKING PAPER SERIES

\title{
TECHNOLOGY, TRADE, AND ADJUSTMENT TO IMMIGRATION IN ISRAEL
}

\author{
Neil Gandal \\ Gordon H. Hanson \\ Matthew J. Slaughter \\ Working Paper 7962 \\ http://www.nber.org/papers/w7962
NATIONAL BUREAU OF ECONOMIC RESEARCH
1050 Massachusetts Avenue
Cambridge, MA 02138
October 2000

For helpful comments we thank Joshua Aizenman, Josh Angrist, Eli Berman, George Borjas, Momi Dahan, Richard Freeman, Doug Irwin, Larry Katz, and seminar participants at Dartmouth College, Harvard University, MIT, the University of Michigan, the 1999 ASSET Meeting, the 1999 CEPR ERWIT Conference, the 1999 NBER ITI Summer Institute, the European Trade Study Group Conference at Rotterdam University, and a CEPR Workshop at University of Bocconi. For financial support Gandal acknowledges the Sapir Center for Development, Hanson acknowledges the National Science Foundation and the Russell Sage Foundation, and Slaughter acknowledges the Russell Sage Foundation. Yasmin Alkalay and Keenan Dworak-Fisher provided excellent research assistance. The views expressed in this paper are those of the authors and not necessarily those of the National Bureau of Economic Research.

(C) 2000 by Neil Gandal, Gordon H. Hanson, and Matthew J. Slaughter. All rights reserved. Short sections of text, not to exceed two paragraphs, may be quoted without explicit permission provided that full credit, including $(\odot$ notice, is given to the source. 
Technology, Trade, and Adjustment to Immigration in Israel

Neil Gandal, Gordon H. Hanson, and Matthew J. Slaughter

NBER Working Paper No. 7962

October 2000

JEL No. F16, F22, J31, J61

\title{
ABSTRACT
}

In the early 1990s Israel experienced a large and concentrated surge of immigration from the former Soviet Union. Most Russian immigrants had high education levels relative to the average Israeli. Despite the size and skill mix of the immigration shock, existing research has found little evidence that it put downward pressure on Israeli wages. In this paper we examine two openeconomy mechanisms through which Israel may have absorbed changes in labor supplies related to the Russian immigration inflow: the adoption of global changes in production technology, and national changes in the mix of traded goods produced. Our main finding is that global changes in production techniques, which appear consistent with skill-biased technical change, were sufficient to more than offset Israel's change in relative factor supplies due to the Russian influx and other events. We also find that changes in output mix (in either traded or nontraded industries) did not help Israel absorb changes in relative factor supplies.

\author{
Neil Gandal \\ Department of Public Policy \\ Tel Aviv University \\ 69978 Tel Aviv \\ Israel \\ and CEPR \\ gandal@post.tau.ac.il \\ Matthew J. Slaughter \\ Department of Economics \\ Dartmouth College \\ 309 Rockefeller Hall \\ Hanover, NH 03755 \\ and NBER \\ slaughter@dartmouth.edu
}

Gordon H. Hanson

Department of Economics

University of Michigan

Ann Arbor, MI 48109

and NBER

gohanson@umich.edu 


\section{Introduction}

In late 1989 the Soviet Union relaxed many emigration restrictions. This policy change, combined with national political and economic unrest, induced a large number of Soviet citizens to leave the country. For Russian Jews, an obvious destination was Israel. ${ }^{1}$ What followed was a large and concentrated immigration wave in Israel. In 1990 and 1991 alone, Russian immigrants swelled the Israeli population by 7.6\%. From late 1989 through 1996 670,000 Russian Jews arrived, increasing the total Israeli population by $11 \%$ and the labor force by $14 \%$. This immigration wave is among the largest the world has ever seen (Friedberg, 1997). Another notable aspect of the Russian immigration was its high-skill composition: relative to the Israeli population as a whole, the new Russian immigrants had high education levels. ${ }^{2}$

Despite the size of this immigration shock, existing research has found only weak evidence that it depressed the wages of Israeli workers. The relative wage of more skilled workers in Israel actually rose during the 1990s, the opposite outcome we would expect given the high-skill composition of the arriving Russians. Dahan (1999) reports an increase in the skill premium in Israel during the period 1990-1996, and Berman (1999) estimates a rise in the return to secular schooling from 1979-1982 to 1993-1996. In work on the Russian immigration itself, Friedberg (1997) finds the impact of immigration on native Israeli wages to be ambiguous. Using OLS, she finds that native Israelis in occupations receiving more immigrants experienced relatively slow wage growth in the early 1990s. But instrumenting for occupation selection by Russian immigrants, she finds no evidence of occupational wage pressures. Eckstein and Weiss (1998) report that Russian immigrants tended to enter the labor force quickly, and that although they initially experienced occupational downgrading this was followed by rapid upgrading. These authors also report no clear evidence that immigrants depressed native Israeli wages.

\footnotetext{
${ }^{1}$ For brevity, throughout the paper we will refer to immigrants from the former Soviet Union as "Russians," although many of these immigrants came from Soviet republics other than Russia.

2 Israel has had larger immigration shocks. From 1948-1951, 687,000 immigrants entered Israel, a population increase of 78\%. In contrast to the Russian influx, the 1948 wave did not change the country's skill composition much (Bank of Israel, 1959).
} 
Wage changes are one possible mechanism for absorbing new immigrants, and one that we would expect to be operating were Israel a closed economy. But Israel is in fact quite open to international trade in goods, ideas, and factors, which create other possible mechanisms through which an economy can adjust to factor-supply shocks. In this paper we examine two openeconomy mechanisms through which Israel may have absorbed changes in labor supplies related to the Russian immigration inflow: the adoption of global changes in production technology, and national changes in the mix of traded goods produced.

Recent literature documents that technological change in many countries around the world has been biased towards more-skilled workers and thus may have contributed to increases in the relative demand for skilled labor. Many early studies in this literature examined the United States (Bound and Johnson, 1992; Katz and Murphy, 1992; Berman, Bound, and Griliches, 1994; Autor, Katz, and Krueger, 1998). More-recent studies have documented that this skill-biased technological change (SBTC) has also occurred in many other countries, and that U.S. SBTC is correlated with the SBTC in these countries (Berman, Bound, and Machin, 1998; Machin and Van Reenen, 1998; Berman and Machin, 1999). This international evidence is often interpreted as "global" SBTC originating in the United States and then flowing abroad through various channels. Israel may have experienced global SBTC, which would have decreased the effective relative supply of more-skilled labor and thus may have offset the increase in the raw relative supply of more-skilled labor associated with the Russian inflow. Following this reasoning, Israel may have absorbed the Russian inflow through blind luck in the form that global technology changes happened to take.

The importance of changes in national output-mix for factor-market adjustment is based on the Rybczynski Theorem (1955), a core result of Heckscher-Ohlin (HO) trade theory. A country may absorb a factor-supply shock without factor-price changes by shifting production towards traded sectors that employ relatively intensively the factors whose relative supplies are expanding. This shift in output mix increases the national relative demand for the factor whose endowment has increased, thereby matching the increase in its national relative supply and 
relieving pressure on factor prices to change. So long as the country is sufficiently small, the output changes do not affect world prices and thus do not trigger Stolper Samuelson-type (1941) factor-price effects. Openness to trade in goods is essential for this mechanism to work, as it allows output changes to be absorbed by changes in exports and imports.

There are reasons to presume ex ante that open-economy adjustment mechanisms matter for Israel. Israel approaches the textbook case of a small open economy: it has free-trade agreements with many countries (including the European Community since 1974 and the United States since 1985), and it accounts for only $0.2 \%$ of world GDP. There is empirical evidence that trade flows are an important mode of technology transfer (Coe and Helpman, 1995; Keller, 1998), and, as just discussed, trade flows facilitate output-mix changes.

To examine how Israel adjusted to the Russian immigration, we use the production side of the HO trade model to decompose changes in factor employments into components associated with changes in production techniques (which reflect technology) and changes in sectoral output (which reflect national output mix). We make no attempt to identify causal linkages between factor-supply changes and other events in Israel. Instead, we seek to identify the contribution of different adjustment mechanisms to how Israel absorbed factor-supply changes during the Russian influx. The usefulness of this approach is that it helps clarify the role of openness in how a country responds to factor-supply shocks in a general-equilibrium setting.

For the empirical analysis we construct a new data set combining Israeli sectoral real value added and sectoral employment of capital and of labor in four education categories: those with less than high school, high-school graduates, those with some college, and college graduates and beyond. The data cover all non-military economic activity in Israel annually from 1980 through 1996. Part of our analysis requires a measure of global technology changes; for this we use output and employment data for the United States, concorded to Israeli sectoral definitions.

Our employment decompositions first break out observed changes in Israeli factor supplies into two components: changes in output across industries and changes in production techniques (factor requirements per unit of output) within industries. To analyze whether global technology 
changes helped Israel absorb factor-supply changes, we further decompose observed changes in production techniques into one part which mimics U.S. changes in production techniques and another part which captures Israel-specific changes in production techniques. U.S. technique changes we interpret as global technology changes. To gauge the role of output-mix changes in factor absorption, we distinguish between traded and nontraded activity.

We have three main findings. First, global SBTC appears to more than offset the increase in Israel's relative supply of skilled workers due to the Russian immigration and other demographic changes. Once we account for global STBC, the effective relative supply of more-educated labor in Israel actually decreased. Second, changes in the output of traded goods added little to factor absorption in Israel. This is true even once we control for global SBTC and factor demand by nontraded sectors. Third, Israel-specific changes in production techniques, which capture Israelspecific changes in factor prices, are more consistent with Israel-specific SBTC than with factorprice changes driven solely by factor-supply changes. Israel appears to have accommodated recent factor-supply shocks through pervasive SBTC which was primarily global in origin.

There are several issues about factor-market adjustment raised by our analysis. The HO model that motivates our work describes long-run equilibria. It is unclear how long it takes an economy to adjust to large endowment shocks, so we look at changes over long time horizons. Since it is total factor supplies that matter in the HO framework, we focus on total Israeli factor supplies and not on just the contribution of Russian immigrants. Relatedly, capital accumulation, through foreign capital inflows or domestic investment, may be another mechanism for absorbing labor-supply shocks (Brezis and Krugman, 1996). We discuss capital accumulation in Israel, but our analysis focuses on other open-economy adjustment mechanisms.

Our findings relate to three bodies of literature. The first is that on how Israel absorbed the Russian immigrants. ${ }^{3}$ The adjustment mechanisms we document may help account for why researchers have not found clear evidence that Russian immigrants put downward pressure on

\footnotetext{
3 Friedberg (1997) discusses other empirical research on immigration in Israel (e.g., Beenstock and Fisher, 1997, and Beenstock and Ben-Menahem, 1997, who simulate the wage impacts of immigration in Israel).
} 
Israeli wages. The second body of literature includes labor-market studies on immigration. Much of this work examines whether immigration depresses native wages in immigrantreceiving regions (see surveys in Borjas, 1994 and Friedberg and Hunt, 1995). The near uniform finding is that immigration has, at most, a small negative effect on wages. Our results suggest that the wage effects of immigration cannot be understood without accounting for the impact of global changes in technology. Such technology shocks may help resolve the puzzle of why immigration does not seem to depress wages.

The third body of literature examines the empirical validity of the HO trade model by seeing whether factor supplies explain the location of production across regions and countries (Harrigan, 1995, 1997; Davis, et al, 1997; Bernstein and Weinstein, 1998; and Davis and Weinstein, 1998).

The Russian immigration shock would seem to be an ideal application for the Rybczynski Theorem (and for the HO model in general) given the sudden and compact nature of this shock and the size and openness of the Israeli economy. That we find changes in traded outputs contribute little to how Israel adjusted to the Russian immigration reflects the limitations of Rybczynski as a comparative-static exercise. Even over short time periods, technological change can swamp the effects of large factor-supply shocks.

The paper has four additional sections. Section 2 documents recent changes in immigration and factor supplies in Israel and discusses institutional details related to the Israeli labor market. Section 3 presents the production side of the HO trade model, from which we develop our empirical strategy. Section 4 presents the main empirical results. Finally, section 5 concludes.

\section{Data Description, The Russian Immigration Shock, and Labor-Market Institutions}

\section{2a. Data Description}

To construct data on the Israeli labor force by education category, we use data from the Israeli Central Bureau of Statistics (CBS) published in the Israeli Labor Force Survey (LFS). An individual is included as part the labor force if he/she resides in Israel and either has a job or is 
looking for work. ${ }^{4}$ For most of the analysis, we use data not on the labor force but on employment by education category and industry. The employment data span all full-time and part-time workers in Israel, including those who reside in the Palestinian territories. These data are constructed by combining data from the Israeli LFS (for the distribution of employment across education categories for Israelis), supplemental CBS data (for total employment of Israelis), and the CBS publication Territories Labor Force Survey (for employment by education category of individuals from the Palestinian territories who work in Israel). The LFS reports number of years of education completed, from which we construct our four skill groups: less than high school (11 years or fewer), high-school graduates (12 years), those with some college (13-15 years), and college graduates and beyond (16 years or more). Data on real industry value added and real industry capital stocks come from the Bank of Israel. Employment, value added, and capital stock data are available annually for 21 industries covering all non-military economic activity in Israel for the period 1980 to 1996.

The employment data just described omit two potentially important groups: legal temporary foreign workers and illegal foreign workers. Temporary foreign workers are contracted to work in Israel for a fixed time period, after which they must return to their home countries (mostly in Eastern Europe and Southeast Asia). The vast majority work in agriculture or construction. Nathanson and Acdut (1999) estimate both the number and sectoral allocation of these workers in Israel for 1985 to 1996 . During the 1980 s there were fewer than 12,000 temporary foreign workers in Israel. After the imposition of entry restrictions on Palestinians in the early 1990s their employment increased dramatically, reaching 85,000 in 1996. We add the Nathanson and Acdut estimates of temporary foreign workers to employment of workers in agriculture and construction from 1985 forward, under the assumptions that no temporary foreign workers have completed high school and that their employment in 1980 was zero. We similarly add in the Nathanson and Acdut estimates of illegal foreign workers as well. ${ }^{5}$

\footnotetext{
4 The labor force data exclude actual and potential workers living outside Israel, e.g., in the Palestinian territories.

5 Overall, our results are robust to whether we include or exclude these foreign workers.
} 
Later in the analysis, we will match the Israeli data to congruent data for the United States. To construct U.S. employment by education level and industry we combine data on the share of employment by education category from the Current Population Survey (CPS) with data on total industry employment from the U.S. Bureau of Economic Analysis (BEA). The BEA is also the data source for U.S. real industry value added and real industry capital stocks. Concording the U.S. and Israeli data require us to aggregate the 21 Israeli sectors up to 19 sectors.

One important issue involved in the construction of the data is whether our four labor education categories are appropriate for Israel. Our choice of categories follows both the recent empirical literature on Israeli and Palestinian labor markets (e.g., Angrist 1995, 1996; Friedberg, 1997) and the large literature on U.S. labor markets. These four categories also appear to be roughly applicable to the organization of the Soviet educational system from the mid-1950s forward (Sheidvasser and Benitez-Silva, 1999). ${ }^{6}$

A second issue is we assume that within a given education category all Israeli workers, whether native or foreign born, are perfect substitutes. Evidence that immigrants earn lower returns to observable skill than do native Israelis suggests that this may not be strictly true. Friedberg (1999) finds that upon arrival in Israel, immigrants have a lower value placed on their origin-country educational attainment and no significant value placed on their origin-country work experience. ${ }^{7}$ Eckstein and Weiss (1998) obtain somewhat different results when looking at changes in earnings over time in Israel for the period 1991-1995. They find that the returns to education for recent immigrants (mostly Russians whose education was acquired abroad) converges partially, but not completely, to the returns for native Israelis; the returns to experience

\footnotetext{
6 One important distinction between the Israeli and Russian educational systems relates to differences in secondary schooling. In Israel it generally takes 12 years to complete secondary schooling. In the Soviet Union the amount of secondary education obtained depended on one's educational objectives. An individual could finish incomplete secondary school in eight years and then pursue a vocational degree (two to three years) or a specialized secondary degree (four years). Alternatively, an individual could finish complete secondary school in 11 or 12 years and then pursue either a technical degree (two to three years) or the equivalent of a university degree (five years). Russian immigrants with 12 years of education thus include a mix of individuals who have finished either complete secondary school or incomplete secondary school plus a specialized secondary degree.

7 Most studies have found that the labor-market returns to education in the Soviet Union were low relative to the returns in developed market economies. For example, Sheidvasser and Benitez-Silva (1999) report estimates of less than 5\%, with no clear rise during the post-reform period of 1992-1999. See also Gregory and Kohlhase (1988) and Katz (1999).
} 
for immigrants converge completely to those for native Israelis; and the returns to unobservable skills are higher for immigrants than for native Israelis. In light of this convergence in returns to education, we think our aggregation scheme is sensible, particularly over longer time periods.

\section{2b. The Russian Immigration Shock}

This section documents recent changes in Israeli factor supplies, with an emphasis on the Russian immigration-shock period. Table 1 provides evidence on the skill composition of Russian immigrants and of the overall labor force. For 1980, 1989, and 1996 it decomposes three labor-force groups in Israel -- Russian immigrants, all other Israeli workers, and all workers -- into shares across the four education categories.

There are two important messages in Table 1. First, the Russian immigration shock was concentrated among the some-college category. The overall change in skill-mix between 1989 and 1996 is broadly the same within each labor-force group: the less-than-high-school share fell while the some-college and college-graduate shares rose. However, the shift towards the somecollege category is much more pronounced among Russian immigrants. From 1989 to 1996 their some-college share grew by 8.4 percentage points more than the some-college share of other Israeli workers ((36.5-24.9)-(21.4-18.2)). In contrast, the college-graduate share grew by 3.5 percentage points for both Russians and other Israelis.

Second, the Russian immigration shock contributed to an ongoing trend of labor-force skill upgrading. In all years in Table 1 the stock of Russian immigrants was concentrated in the higheducation categories relative to the rest of the labor force. But during the 1980 s there already was a shift in Israel towards more-educated workers, due mainly to large numbers of moreeducated, young, native Israelis entering the labor force. Seen in this context, what is notable about the Russian influx is not so much the direction of the shift in labor-force composition but rather its unanticipated contribution to the process of skill upgrading.

Figure 1 plots the Russian immigrant share of the total Israeli labor force by education group. The overall size of the inflow is plainly visible in the sharply rising Russian share in all four 
categories after 1990. The relative skill composition of the inflow appears as the much larger increase in shares for college graduates and, most of all, those with some college. Between 1990 and 1994, the Russian immigrant shares of those with some college rose from $8.7 \%$ to $24.1 \%$ and of college graduates rose from $7.6 \%$ to $20.2 \%$. In contrast, the Russian immigrant share of highschool graduates rose only from $3.4 \%$ to $7.3 \%$.

Figure 2 shows the contribution of non-Russian immigrants to the Israeli labor force. Many of these individuals have resided in Israel for several decades (Friedberg, 1997 and 1999). For other immigrants the largest labor-force shares are in the least-educated categories. ${ }^{8}$ The falling labor-force shares across all education categories for other immigrants shows that this group's relative importance in the Israeli labor force has been declining over time.

One important issue is whether capital accumulation in Israel helped the economy absorb the change in relative factor supplies. If physical capital substitutes for less-skilled labor and complements more-skilled labor, then increased capital accumulation, via domestic investment or foreign capital inflows, could have relieved wage pressures from rising relative supplies of moreeducated workers. Figure 3 presents evidence on capital accumulation in Israel plotting the capital-total employment ratio and the GDP-total employment ratio, both in logs, over the sample period. Capital per worker declined during the height of the Russian immigrant inflow of 19901992, which suggests that initially capital accumulation did not keep pace with employment growth and thus did not play a big role in labor-market adjustment in Israel. We return to this issue later. Throughout the period capital and output per worker tend to increase together, but during 1990-1992 output per worker continued to increase even though capital per worker declined. This growth in output per worker is consistent with an increase in the average skilllevel of the Israeli workforce, attributable at least in part to the Russian influx. It is also consistent with growth in labor productivity due to technological change.

\footnotetext{
8 Other Israeli immigrants include two sizable groups: more-educated individuals from Western Europe and the United States, and less-educated individuals from North Africa. See Friedberg (1999) for details on the skill mix of these immigrants.
} 


\section{2c. Labor-Market Institutions and Immigrant Entry into the Labor Force}

Taken together, the data suggest that the Russian immigration shock helped shift Israel's labor endowment towards more-educated workers, particularly the some-college category. The obvious next question is how fast did arriving Russians obtain jobs.

All else equal, rigid labor-market institutions in Israel could either inhibit entry of Russian immigrants into the labor force or constrain wage adjustment in response to their entry. While Israel has historically been an economy characterized by active unions and collective wagesetting arrangements, Artstein (1999) reports that during the 1980s and 1990s labor markets grew more flexible as these institutions became less important. For example, union membership declined from $61 \%$ in 1981 to $47 \%$ in 1994 . There was also an economy-wide increase in the use of individual wage contracts, particularly in a rapidly growing market for temporary employment, with a commensurate decline in the share of total compensation accounted for by collective wage bargaining. The share of the total change in wages accounted for by collective wage agreements declined from $81.4 \%$ in the early 1980 s to $27.7 \%$ in the mid 1990 s. Overall, it is clear that labormarket institutions are an important feature of the Israeli labor market—but it also appears their role was declining before and during the Russian immigration shock. ${ }^{9}$

This is not to say that the arriving Russians immediately found jobs in skill-appropriate occupations. As for finding jobs, Figure 4 reports unemployment rates for two groups in Israel: Russian immigrants and all other workers. Prior to the Russian influx in 1990, unemployment rates for Russian immigrants were consistently lower than those of all other workers. From 1990 onwards this pattern is reversed. The unemployment rate for Russian immigrants nearly tripled between 1989 and 1991. But in subsequent years this unemployment rate declined quite rapidly, such that by 1996 it was within two percentage points of the rate for all other Israelis.

Part of what helped ease the entry of Russian immigrants into the Israeli economy were public and private institutions dedicated to helping new immigrants in Israel, many of which are

\footnotetext{
${ }^{9}$ See Bank of Israel (1991) for a discussion of the interaction between labor-market institutions and immigrant assimilation.
} 
coordinated by the Ministry of Immigrant Absorption (MIA). The MIA organizes Hebrew courses for new immigrants and gives a stipend to help cover expenses during language training. To accredit foreign education the Ministry of Education maintains a Department for the Evaluation of Overseas Degrees. The MIA conducts courses to help immigrants prepare for professional licensing exams and to retrain immigrants in different occupations. The Center for Absorption in Science helps match arriving scientists with Israeli employers. And to facilitate the absorption of immigrant entrepreneurs the MIA runs entrepreneurship centers, which provide assistance with obtaining start-up capital. ${ }^{10}$

As for finding skill-appropriate employment, Eckstein and Weiss (1998) report substantial occupation downgrading for arriving Russian immigrants followed by rapid resorting thereafter. For example, only $18.7 \%$ of arriving engineers were employed in the highest-skill occupation category after six months, but the share rose to $42.6 \%$ four years later. It is important to note that the Heckscher-Olin model does not require that Russian immigrants gain employment in Israel in their original occupations, but only that they gain employment in occupations matched to their levels of human capital. Occupational mobility, among existing workers and/or among entrants to the labor force, is likely to be necessary for changes in output mix to occur. That many highlyeducated Russians eventually found high-skill jobs outside of their original occupations, as Eckstein and Weiss document, is consistent with this line of reasoning.

We interpret Figure 4 and its related discussion to suggest that although it took time for arriving Russians to find skill-appropriate jobs in Israel, unemployment was not a persistent adjustment mechanism. Employment of the arriving Russians, however, did not appear to involve substantial wage adjustments. Dahan (1999) reports rising skill premia during the 1990s, not falling premia as Table 1 and Figure 1 would suggest. Table 2 reports Dahan's estimates of the return to education for native Israelis over the period 1980-1996. In 1990 workers with at

\footnotetext{
10 The Ministry of Immigrant Absorption web site (http://www.moia.gov.il/english/types/types.html) contains detailed information about institutions which facilitate immigrant labor-force entry. It is notable that many of these institutions are now tailored to Russians (e.g., the majority of entrepreneurship centers have Russian-speaking counselors).
} 
least 16 years of education earned $48 \%$ more than those with five to eight years of education, $26 \%$ more than those with 11-12 years, and 6\% more than those with 13-15 years. In 1996 these premia had risen to $57 \%, 35 \%$, and $15 \%$, respectively. These results accord with estimated returns to schooling in Berman (1999). Overall, the wage evidence suggests that other adjustment mechanisms were at work. We now turn to this issue.

\section{Open-Economy Adjustment Mechanisms in the Heckscher-Ohlin Model}

Openness to international trade in ideas and products creates mechanisms other than wage changes through which an economy can adjust to factor-supply shocks. We will focus on two such mechanisms: the adoption of global changes in production technology, and national changes in the mix of goods produced. Before presenting our empirical approach, we first provide some evidence on whether these two mechanisms were operating in Israel.

\section{3a. Initial Evidence on Global Technological Change and Output-Mix Changes}

It appears that in recent decades skill-biased technical change (SBTC) has occurred in many countries and that U.S. SBTC is correlated with the SBTC in these countries. In a given country, a central piece of evidence for SBTC is within-industry increases in the employment of skilled workers relative to unskilled workers despite constant or rising skill premia. The main evidence for global SBTC is that the pattern of within-industry skill upgrading looks similar across countries - in particular, similar to the U.S. pattern. There are a large number of empirical studies presenting this evidence, and we will follow the common precedent of interpreting production-technique changes as resulting from exogenous production-technology changes. ${ }^{11}$

Figure 5 presents evidence of global SBTC in Israel during the period of the Russian immigration shock, 1989-1996, and the preceding period, 1980-1989. For each period this figure displays a scatterplot of level changes in the skilled-labor share of total industry employment

\footnotetext{
11 Acemoglu (1999) models how firms endogenously decide to implement new skill-biased technologies.
} 
(where we define skilled workers as those with more than 12 years of education) in U.S. industries against changes in that share in Israeli industries. ${ }^{12}$ In each scatterplot there is a 45 degree line through the origin to show equal employment shifts between the two countries.

In every Israeli industry but mining in the 1980s and agriculture in the 1990s, the skilledlabor employment share rose during both periods despite the rising Israeli skill premium. Moreover, the shifts in Israeli employment shares broadly match those in the United States. The weighted correlation for employment-share changes is 0.27 in the $1980 \mathrm{~s}$ and 0.48 in the $1990 \mathrm{~s}$ (the latter statistically significant at the 5\% level). Overall, this evidence suggests that Israel was experiencing skill upgrading (SBTC) similar to skill upgrading (SBTC) in the United States. The extent of skill upgrading in the two countries appears to differ across the two decades, however. In the $1980 \mathrm{~s} 12$ of the 19 industries had less-extensive skill upgrading in Israel. In the 1990s the situation reversed, with 16 of the 19 industries having more-extensive skill upgrading in Israel. This difference across decades is consistent with the hypothesis that in recent decades global SBTC has largely originated in the United States and then flowed to other countries with some time lag. We present further evidence on this hypothesis in the next section.

There are many linkages between the United States and Israel which could facilitate technology flows. One is bilateral trade. From 1980 to 1996, the United States accounted for $30.0 \%$ of Israeli exports and $19.2 \%$ of Israeli imports. A second linkage is capital flows. In 1996 105 U.S. firms had affiliates in Israel, which employed 48,100 workers $(2.4 \%$ of Israeli employment) of which 10,000 worked in electronic equipment, a highly technology-intensive industry. Over 100 Israeli corporations are listed on the NASDAQ, and U.S. venture-capital funds have increased investments in Israel during the 1990s. Many U.S. firms (IBM, Intel, Motorola, National Semiconductor) have R\&D labs in Israel, which frequently exchange personnel with U.S.-based labs. In 1996 U.S. firms performed \$166 million worth of R\&D in Israel (5.9\% of 1996 foreign investment in Israel). A third linkage is government activities.

\footnotetext{
12 Figure 5 parallels Figure III in Berman, Bound, and Machin (1998, p. 1264). For the reported correlation coefficients, each industry is weighted by its share of Israeli GDP averaged over the start and end years of the relevant decade.
} 
Many U.S. states have business-development agreements with Israel. The U.S.-Israel Binational Science Foundation, founded in 1972, funds joint work between U.S. and Israeli scholars.

Table 3 presents more evidence of skill upgrading in Israel. For each industry in 1980 and 1996, we list four measures of industry factor intensity: the ratios of employment of college graduates, those with some college, high-school graduates, and capital to employment of those with less than high school. ${ }^{13}$ Widespread SBTC is suggested by the pervasive within-industry decline in the relative employment of less-educated workers. Every industry shows a rise in the relative employment of college graduates and those with some college.

Table 4 presents initial evidence on output-mix changes in Israel. For two periods, 19801989 and 1989-1996, Table 4 reports each industry's share in national GDP in the initial and final years and the level change in each industry's share over the period. It is apparent in Table 4 that in Israel, as in many developed countries, most economic activity is in the nontraded sector. The nontraded industries - construction; government; trade and services; and water, power, and transportation - account for about $75 \%$ of Israeli GDP (see note 13 ).

During the immigration-shock period, changes in both nontraded and traded output-mix patterns appear to mandate labor-demand shifts away from more-skilled workers, the opposite of actual supply shifts towards this group. As for nontradeds, the economy's fastest growing industry was construction, due in part to increased housing demand created by the immigration boom; construction was also the economy's least skill-intensive industry. In contrast, the economy's second-slowest-growing industry was government, due in part to cutbacks in defense spending; government was also the economy's most skill-intensive industry. Among traded goods, while the fastest-growing industry, electrical equipment, was also the most skill-intensive traded industry, other fast-growing tradables (e.g., nonmetallic minerals and wood products) were less skill-intensive while other skill-intensive tradables (e.g., transportation equipment and machinery) were slow growing. Weighting each industry by its GDP share averaged over 1989

\footnotetext{
13 Government includes public administration and health, educational, and social (membership organizations, including religious
} institutions) services. Trade and services includes wholesale and retail trade, finance, insurance, real estate, and other services. 
and 1996, the correlation between the 1989-1996 change in GDP share and 1996 relative employment of skilled workers (those with more than 12 years of education) is -0.65 (significantly different from zero at the 1\% level). Overall, Table 4 suggests that output-mix changes alone cannot account for observed labor-supply changes.

\section{3b. Heckscher-Ohlin Production Theory}

In this section we present the production side of $\mathrm{HO}$ trade theory. We use this to develop a set of decompositions which show the different mechanisms through which an economy can absorb changes in factor supplies.

For small open economy like Israel let there be $\mathrm{N}$ total industries and $\mathrm{M}$ primary factors of production. For each industry assume technology is constant returns to scale and free of externalities. Factor-market equilibrium implies supply equals demand, or

$$
\text { (1) } \mathbf{V}=\mathbf{C X} \text {, }
$$

where $\mathbf{V}$ is an Mx1 vector of national primary factor supplies; $\mathbf{X}$ is an Nx1 vector of national real value-added output; and $\mathbf{C}$ is an $\mathrm{MxN}$ matrix of unit factor requirements (industry production techniques), such that element $c_{m n}$ shows the units of factor $m$ required to produce one unit of real value added in industry $n$. A second equilibrium condition is that profits are zero, or

$$
\text { (2) } \mathbf{P}=\mathbf{C}^{\prime} \mathbf{W} \text {, }
$$

where $\mathbf{W}$ is an Mx1 vector of national factor prices and $\mathbf{P}$ is an Nx1 vector of exogenously given world product prices. Equation (2) says that prices equal average costs. For (2) to hold as an equality, as we assume, the country must produce all $\mathrm{N}$ goods. Factor prices in (2) are not indexed by industry: perfect intersectoral factor mobility ensures that each factor earns the same wage in all sectors. In the equilibrium described by equations (1) and (2), $\mathbf{P}$ and $\mathbf{V}$ are exogenously given at each point in time; $\mathbf{X}$ and $\mathbf{W}$ are determined endogenously as a function of $\mathbf{P}, \mathbf{V}$, and production technology; and the $\mathbf{C}$ matrix depends on technology and $\mathbf{W} .1415$

\footnotetext{
14 Industry production techniques are usually stated in terms of net output, not value added. See Hanson and Slaughter (2000) on issues related to using value added instead of net output.
} 
We build on equation (1) to identify the mechanisms through which national factor-supply changes are absorbed. Taking first differences of (1),

\section{(3) $\Delta \mathbf{V}=\overline{\mathbf{C}} \Delta \mathbf{X}+\Delta \mathbf{C} \overline{\mathbf{X}}$}

where $\Delta$ is the time-difference operator and $\overline{\mathbf{Y}}$ is the mean of $\mathbf{Y}$ across time. Equation (3) decomposes a country's change in factor supplies $(\boldsymbol{\Delta V})$ into two portions: that accounted for by output-mix changes (first term on the right) and that accounted for by production-technique changes (second term on the right). Equation (3) is similar to the within- versus betweenindustry decompositions of employment changes that are commonly applied in labor literature (e.g., Katz and Murphy, 1992; Berman, Bound, and Griliches, 1994). Part of what makes our approach distinct in that we exploit the fact that the $\mathbf{C}$ matrix is a general-equilibrium outcome, which can be compared across countries. We will use changes in the U.S. C matrix to gauge the importance of global technology shocks for Israel. Additionally, we will separate traded from nontraded goods, to gauge the importance of traded-output-mix changes for factor absorption.

As indicated, most research on the labor-market impact of immigration has focused on the closed-economy adjustment mechanism of wage changes. Even in an open economy like Israel's, the Russian immigration could have changed factor prices. If the Russian inflow did trigger wage effects, what would equation (3) show? Given the skill-composition of the immigration shock (see Table 1), we would expect the Israeli skill premium to fall. This fall, in turn, would induce firms to substitute towards more-skilled workers and away from less-skilled workers. If this were the only factor-demand mechanism absorbing factor-supply changes, then (3) would show that $\Delta \mathbf{V}=\Delta \mathbf{C} \overline{\mathbf{X}}$ (i.e., $\overline{\mathbf{C}} \boldsymbol{\Delta} \mathbf{X}=\mathbf{0}) .{ }^{16}$

To examine the role of international flows of technology and trade in factor absorption, equation (3) needs two modifications. First, we need to separate changes in production

\footnotetext{
15 It is possible to relax equation (2) to allow for constant price-cost markups or interindustry wage differentials.

16 Wages could change in a small open economy if $\mathrm{N}<\mathrm{M}$ or if $\mathrm{N} \geq \mathrm{M}$ but $\boldsymbol{\Delta} \mathbf{V}$ is sufficiently large to shift the economy into a new cone of diversification with a new set of produced goods. In this latter case the mix of goods produced would change, both among tradables and perhaps nontradables, rendering $\mathbf{\Delta X}$ different from zero. For a large open economy, changes in output supplies (caused by the change in factor supplies) would change world relative prices, which would then induce Stolper Samuelson-type (1941) changes in factor prices and industry production techniques as well.
} 
techniques attributable to global technology shocks from those attributable to Israel-specific events. Second, we need to distinguish between adjustments in traded and nontraded sectors.

Global changes in production technology would change Israeli production techniques, either directly, through shifts in factor demand, or indirectly, through changes in global product prices and thus Israeli factor prices. ${ }^{17}$ As discussed in section 3a, there is reason to suspect that during our sample period Israel was experiencing global SBTC broadly similar to that of the United States. Accordingly, we want to account for these global technology shocks in our analysis. This would be difficult to do with data for Israel only; our strategy is to measure these shocks using data on production-technique changes in the United States.

To identify the possible role of such global shocks in Israeli factor absorption, we distinguish changes in production techniques that are global, $\Delta \mathbf{C}_{\mathbf{G}}$, from those that are idiosyncratic to Israel, $\Delta \mathbf{C}_{\mathbf{I}}$. We calculate $\Delta \mathbf{C}_{\mathbf{G}}$ as the Israeli $\mathbf{C}$ matrix in the initial year times the percentage change in U.S. production techniques (on a by-industry and by-factor basis) over the given time period. That is, we define $\Delta \mathbf{C}_{\mathbf{G}}$ to be an $\mathrm{MxN}$ matrix whose $m n$th element is given by:

$$
\text { (4) } \Delta \mathrm{c}_{\mathrm{G}, \mathrm{mn}}=\mathrm{c}_{0, \mathrm{mn}} \times \hat{\mathrm{c}}_{\mathrm{mn}}^{\mathrm{US}}
$$

where $\mathrm{c}_{0, \mathrm{mn}}$ is the $m n$th element of $\mathbf{C}_{\mathbf{0}}$ and $\hat{\mathbf{c}}_{\mathrm{mn}}^{\mathrm{US}}$ is the $m n$th of the $\mathrm{MxN}$ matrix, $\hat{\mathbf{C}}^{\mathbf{U S}}$, which shows percentage changes in the elements of the U.S. factor-requirement matrix, $\mathbf{C}^{\mathbf{U S}}$. So to calculate $\Delta \mathbf{C}_{\mathbf{G}}$ we take each element of the initial Israeli $\mathbf{C}$ matrix and scale it up or down by the percentage change in the corresponding element of $\mathbf{C}^{\mathbf{U S}} \cdot \Delta \mathbf{C}_{\mathbf{I}}$ is then the residual change:

$$
\text { (5) } \Delta \mathbf{C}_{\mathbf{I}}=\Delta \mathbf{C}-\Delta \mathbf{C}_{\mathbf{G}} \text {. }
$$

Substituting (5) into (3) we obtain a new decomposition,

$$
\text { (6) } \Delta \mathbf{V}=\overline{\mathbf{C}} \Delta \mathbf{X}+\Delta \mathbf{C}_{\mathbf{G}} \overline{\mathbf{X}}+\Delta \mathbf{C}_{\mathbf{I}} \overline{\mathbf{X}} \text {. }
$$

Note that if global technological change is biased towards specific factors, then the implied demand shifts can be thought of as a change in effective factor supplies (Davis, 1998). In particular, global SBTC, suggested in Figure 5, may have helped Israel absorb increases in the

\footnotetext{
17 Of course, global product-price changes could also arise from other forces such as trade liberalization or taste changes.
} 
raw relative supply of more-educated workers by reducing this group's effective relative supply. If global technology changes were the only factor-demand mechanism absorbing factor-supply changes, then we would find that $\Delta \mathbf{V}=\Delta \mathbf{C}_{\mathbf{G}} \overline{\mathbf{X}}$ and that $\overline{\mathbf{C}} \Delta \mathbf{X}=\Delta \mathbf{C}_{\mathbf{I}} \overline{\mathbf{X}}=\mathbf{0}$.

In (6), $\Delta \mathbf{C}_{\mathbf{I}} \overline{\mathbf{X}}$ captures factor-demand shifts accounted for by any Israel-specific changes in production techniques. What might cause these? One possibility is wage adjustments associated with the Russian immigration shock and other factor-supply changes. As discussed above, we would expect these wage adjustments to induce substitution away from less-skilled workers and towards more-skilled workers. A second possibility is wage adjustments associated with changes in Israel's labor-market institutions, as discussed in section 2c. Since these institutions typically compress the wage distribution, we would expect their relaxation to raise the skill premium, which would induce substitution towards less-skilled workers and away from more-skilled workers. A third possibility is changes in technology that are specific to Israel. Figure 5 suggests that in the 1990s Israel experienced greater SBTC than did the United States, which would result in substitution away from less-skilled workers and towards more-skilled workers.

Having accounted for global technology shocks, next consider the role of output-mix changes among traded goods. By shifting into sectors that use intensively factors whose supplies are expanding, an economy can absorb factor-supply changes without changes in factor prices. This logic, however, applies only to traded goods for which output is not constrained by domestic demand. As for nontraded goods, when the economy grows (e.g., due to growing factor supplies) consumer preferences mandate changes in nontraded output which in turn mandate changes in factor demand (Helpman and Krugman, 1985). For Israel, the obvious example of this is the boom in housing demand triggered by the Russian shock (see Table 4). To assess the contribution to factor absorption of changes in traded output, we must account for factor absorption due to nontraded goods (Davis and Weinstein, 1999). Define $\mathbf{I}^{\mathbf{N T}}\left(\mathbf{I}^{\mathbf{T}}\right)$ to be an NxN matrix with zero off-diagonal elements and diagonal elements equal to one if the column corresponds to a nontraded (traded) sector and zero otherwise. Also, define $\mathbf{X}^{\mathbf{N T}} \equiv \mathbf{I}^{\mathbf{N T}} \mathbf{X}$ and $\mathbf{X}^{\mathbf{T}} \equiv \mathbf{I}^{\mathbf{T}} \mathbf{X}$. We then rewrite equation (6) as 
(7) $\Delta \mathbf{V}=\left(\overline{\mathbf{C}} \Delta \mathbf{X}^{\mathrm{T}}+\Delta \mathrm{C}_{\mathrm{G}} \overline{\mathbf{X}}^{\mathrm{T}}+\Delta \mathrm{C}_{\mathrm{I}} \overline{\mathbf{X}}^{\mathrm{T}}\right)+\left(\overline{\mathbf{C}} \Delta \mathbf{X}^{\mathrm{NT}}+\Delta \mathrm{C}_{\mathrm{G}} \overline{\mathbf{X}}^{\mathrm{NT}}+\Delta \mathrm{C}_{\mathrm{I}} \overline{\mathbf{X}}^{\mathrm{NT}}\right)$

The first (second) term on the right in equation (7) shows factor absorption by the traded (nontraded) sector. If changes in traded outputs were the only factor-demand mechanism absorbing factor-supply changes (expressed appropriately as net of any factor absorption by nontraded output changes), then we would find that $\Delta \mathbf{V}-\overline{\mathbf{C}} \Delta \mathbf{X}^{\mathbf{N T}}=\overline{\mathbf{C}} \Delta \mathbf{X}^{\mathbf{T}}$.

To summarize this section, we have presented the production side of HO trade theory linking factor and product markets. In doing this we have motivated the employment decompositions in equations (3), (6), and (7). These decompositions will indicate the mechanisms through which Israel has absorbed factor-supply changes. Global technology shocks are captured by $\Delta \mathbf{C}_{\mathbf{G}} \overline{\mathbf{X}}$; traded-output-mix changes are captured by $\overline{\mathbf{C}} \Delta \mathbf{X}^{\mathbf{T}}$; and both Israel-specific technology shocks and factor-supply-shock-related wage changes are captured by $\Delta \mathbf{C}_{\mathbf{I}} \overline{\mathbf{X}}$. Note that both Israelspecific technology shocks and immigration-related wage changes imply the same movements in $\Delta \mathbf{C}_{\mathbf{I}} \overline{\mathbf{X}}$ : substitution away from (towards) less-skilled (more-skilled) workers. Distinguishing these two forces hinges on changes in relative wages: immigration-related adjustments imply a declining skill premium, but SBTC-related adjustments probably imply a rising skill premium.

Before presenting our results, a few qualifications about these decompositions are in order. First, these decompositions all hold as identities and thus cannot identify causal relationships among $\Delta \mathbf{V}, \Delta \mathbf{X}$, and $\Delta \mathbf{C}$. Their usefulness is to uncover the mechanisms through which Israel absorbs factor-supply changes. Relatedly, we again point out we do not consider whether $\Delta \mathbf{V}$ is itself an absorption mechanism, but we acknowledge that international factor flows may matter. For instance, foreign direct investment in Israel in the 1990s may have mitigated the wage impact of labor-supply changes. We return to this issue in section $5 .{ }^{18}$

\footnotetext{
18 One might ask why we do not use a regression framework to examine the impact of factor-supply changes on output changes and production-technique changes. One approach, following Harrigan $(1995,1997)$, would be to pool industries over time to estimate the fraction of output-supply changes explained by factor-supply changes, technological change, and other possible forces. There are at least three problems with this approach, however, which lead us to favor our accounting decompositions. First, unlike our decompositions, this regression would not directly answer the key question of what fraction of factoremployment changes are absorbed by output changes, holding production techniques constant. Second, recent work by Bernstein and Weinstein (1999) raise important concerns about this regression's interpretation for the case where there are more industries than there are factors of production (as appears to be our case). Third, if technology is changing — as our data strongly suggestwe would need data on a large cross-section of countries to estimate its effects.
} 
Second, the decomposition in (7) assumes both that changes in U.S. production techniques reflect global technology shocks and that both countries respond similarly to these shocks. ${ }^{19}$ Again, the first assumption is based on the international evidence of SBTC. A sufficient condition for the second assumption to be true is that there be factor-price equalization (FPE) between the two countries. This is at least plausible: the two countries have a free-trade agreement in place for most of our sample period and share substantial bilateral flows of goods and factors. For our purposes, it would be sufficient that there is productivity-adjusted FPE between Israel and the United States. This would permit wage differences between the two countries attributable to industry-neutral factor productivity differences (Trefler, 1993; Hanson and Slaughter, 2000). Even in the absence of FPE, changes in U.S. production techniques are likely to be informative about global technology shocks facing Israel.

Finally, to ensure the decompositions conform with HO theory's full-employment conditions we measure $\mathbf{V}$ as total employment. We thus miss a role for unemployment in factor-market adjustment. One could measure $\mathbf{V}$ as total factor supplies, in which case changes in the stock of unemployed factors would be an additional decomposition term. We do not do this because we lack data on capacity utilization and because it is unclear how to determine the "potential" Israeli labor force given the importance of Palestinian and temporary foreign workers. Figure 4 suggests that unemployment plays a relatively small role in long-term labor-market adjustment.

\section{Empirical Results}

We apply equations (3), (6), and (7) to Israeli data for two time periods: $1980-1989$ and 1989-1996. We take multi-year differences in light of the evidence that it took time for arriving Russians to find skill-appropriate jobs in Israel. We choose 1989 as the breakpoint because late 1989 was when the Russian inflow started. All decompositions are performed on a factor-byfactor basis. We modify the decompositions by dividing each $\mathbf{V}$ element and each $\mathbf{X}$ element in

19 Also, there may be other global shocks, such as to prices (see note 15). And U.S. production techniques may change due to purely domestic shocks. Even so, such shocks are likely to be transmitted to world markets given the size of the U.S. economy. 
equation (1) by total Israeli employment. Thus, the elements of $\Delta \mathbf{V}$ are shifts in relative factor supply and the elements of the demand-shift vectors are shifts in relative factor demand.

\section{4a. Global Technology Shocks and Factor Absorption}

Table 5 combines the decompositions in equations (3) and (6). Column (1) shows $\Delta \mathbf{V}$, the change in factor supplies; column (2) shows $\overline{\mathbf{C}} \boldsymbol{\Delta} \mathbf{X}$, average production techniques times the change in industry output (summed over all industries); and column (3) shows $\Delta \mathbf{C} \overline{\mathbf{X}}$, the change in production techniques times mean industry output (summed over all industries). Columns (4) and (5) then show $\Delta \mathbf{C}_{\mathbf{G}} \overline{\mathbf{X}}$ and $\Delta \mathbf{C}_{\mathbf{I}} \overline{\mathbf{X}}$, which represent factor absorption due to global changes and Israel-specific changes, respectively, in production techniques (see equations (4) and (5)). Column (6) reports the quantity $\left(\Delta \mathbf{V}-\Delta \mathbf{C}_{\mathbf{G}} \overline{\mathbf{X}}\right)$, the raw change in factor employments minus factor absorption attributable to global changes in production techniques.

There are three important results in Table 5. First, in both decades qualitative changes in factor supplies are not matched by qualitative changes in output mix. Column (1) shows that in both decades there was an increase in the relative supply of more-educated workers, as evidenced by the decline in employment shares for less-educated workers (except for high-school graduates in the 1980s) and the rise in employment shares for more-educated workers (consistent with the labor-force shifts in Table 1). Yet, column (2) shows that output changes were mandating the opposite shift in factor demand: in both decades output changes were mandating a decrease in the relative demand for more-skilled workers, as evidenced by the larger mandated increases in employment shares for less-educated workers compared to more-educated workers (consistent with the industry-level evidence in Tables 3 and 4). In each decade it was changes in production techniques, in column (3), that mandated a shift in factor demands away from the less-educated and towards the more-educated, as evidenced by the large mandated declines in employment shares for less-educated workers and the mandated increases in employment shares for moreeducated workers. These results are similar to those for the United States during similar time periods (Katz and Murphy, 1992; Berman, Bound, and Griliches, 1994). 
Second, for most factors the contribution of production techniques to factor absorption (column (3)) are largely accounted for by global changes (column (4)) and not Israel-specific changes (column (5)). In both decades the global technique changes show sharp declines in the relative demand for less-skilled workers, consistent with global SBTC. During the immigrationshock period (1989-1996) global technique changes account for at least two-thirds of observed technique changes for all four labor factors. In isolation, column (3) suggests that Israel was experiencing SBTC in both decades - particularly in light of the concomitant rise in the Israeli skill premium. The additional evidence in columns (4) and (5) suggests that Israel's SBTC may have been due largely to global technology shocks.

The Israel-specific technique changes in column (5) suggests that Israel experienced less SBTC than the rest of the world during the 1980s but more during the 1990s. In the 1980s these changes mandated a shift in labor demand towards less-skilled workers, but in the 1990s they mandated a shift away from less-skilled workers. While these 1990s shifts could also reflect wage adjustments related to the Russian immigration, this story is inconsistent with the rising skill premium in Israel. Note that these cross-decade differences in Israel-specific technique changes match the cross-decade differences in Israel's skill upgrading displayed earlier in Figure 5. Given that we proxy global technique changes using U.S. data, column (5) and Figure 5 accord with the hypothesis that in recent decades global SBTC has largely originated in the United States and flowed to other countries with a time lag.

Third, factor-supply changes net of global technique changes (column (6)) are very different from raw factor-supply changes (column (1)). In both decades raw changes in factor supplies show an increase in the relative supply of skilled labor, but effective changes in factor supplies net of global technique changes actually show the opposite. Because global SBTC triggers decreased use of less-skilled workers and increased use of more-skilled workers, it works like a fall in the relative supply of skilled labor. Here global SBTC appears to be so extensive that its implied labor-supply shifts actually swamp raw labor-supply shifts. 


\section{4b. Changes in Output Mix and Factor Absorption}

Having documented the role played by global technique changes in factor absorption in Israel, we now turn to the contributions of traded and nontraded industries. Table 6 reports the decomposition in equation (7). Column (1) again shows $\Delta \mathbf{V}$, the change in actual factor supplies; columns (2) and (5) show $\overline{\mathbf{C}} \boldsymbol{\Delta} \mathbf{X}^{\mathbf{T}}$ and $\overline{\mathbf{C}} \boldsymbol{\Delta} \mathbf{X}^{\mathbf{N T}}$, average production techniques times the change in industry output in traded and nontraded industries, respectively; columns (3) and (6) show $\Delta \mathbf{C}_{\mathbf{G}} \overline{\mathbf{X}}^{\mathbf{T}}$ and $\Delta \mathbf{C}_{\mathbf{G}} \overline{\mathbf{X}}^{\mathbf{N T}}$, generalized changes in production techniques times mean industry output in traded and nontraded industries, respectively; and columns (4) and (7) show $\Delta \mathbf{C}_{\mathbf{I}} \overline{\mathbf{X}}^{\mathbf{T}}$ and $\Delta \mathbf{C}_{\mathbf{I}} \overline{\mathbf{X}}^{\mathbf{N T}}$, Israel-specific changes in production techniques times mean industry output in traded and nontraded industries, respectively.

As in Table 5, we see in Table 6 that in both decades qualitative changes in actual factor supplies are not matched by qualitative changes in output mix in either traded or nontraded industries. Output changes in both traded and nontraded industries (columns (2) and (5)) mandated a shift in relative labor demand towards less-skilled workers, working against the actual shifts in relative labor supply (column (1)). Thus, the demand shifts mandated by output changes in all sectors together, in Table 5, are qualitatively the same between traded and nontraded sectors. This is consistent with the industry-level evidence in Table 4.

Turning to the changes in production techniques in Table 6 , we see that both generalized and Israel-specific changes in production techniques occurred in both the traded and nontraded sectors. The generalized changes indicate shifts in relative demand away from less-skilled workers in both tradables and nontradables, suggesting global SBTC was occurring in both traded and nontraded industries in both decades. In many cases the nontraded shifts are larger than the traded shifts, consistent with the larger size of the nontraded sector.

It appears in Table 6 that traded-output-mix changes do not match the shifts in actual factor supplies. In motivating this table's decomposition, equation (7), we noted that if changes in traded outputs were the only factor-demand mechanism absorbing factor-supply changes then we would find that $\Delta \mathbf{V}-\overline{\mathbf{C}} \Delta \mathbf{X}^{\mathbf{N T}}=\overline{\mathbf{C}} \Delta \mathbf{X}^{\mathbf{T}}$--i.e., that traded-output-mix changes would match shifts 
in factor supplies net of nontraded-output-mix changes. But we know from Table 5 that global technology changes were an important absorption mechanism. Accordingly, the role of tradedoutput-mix changes should be compared with factor-supply changes net of both global technique changes and nontraded-output changes.

Table 7 reports results for this comparison. Column (1) again shows $\Delta \mathbf{V}$, the change in actual factor supplies; column (2) shows $\Delta \mathbf{V}-\overline{\mathbf{C}} \Delta \mathbf{X}^{\mathbf{N T}}$, actual factor-supply changes net of nontradedoutput changes; column (3) shows $\Delta \mathbf{V}-\overline{\mathbf{C}} \Delta \mathbf{X}^{\mathbf{N T}}-\Delta \mathbf{C}_{\mathbf{G}} \overline{\mathbf{X}}$, actual factor-supply changes net of both global technique changes and nontraded-output changes; column (4) shows $\overline{\mathbf{C}} \Delta \mathbf{X}^{\mathbf{T}}$, average production techniques times the change in industry output in traded industries; and column (5) shows $\Delta \mathbf{C}_{\mathbf{I}} \overline{\mathbf{X}}$, Israel-specific changes in production techniques times average industry output. Note that by construction, columns (4) plus (5) equal column (3).

In each decade columns (1) and (3) look quite different; in particular, during the 1980s raw labor supply shifted away from less-skilled workers but effective labor supply shifted towards them. This suggests that during periods of extensive factor-biased technological change, raw changes in factor supplies may be a poor indicator of changes in factor supplies net of this technological change - and thus a poor indicator of the changes in traded output.

That said, however, the main message of Table 7 is that traded-output-mix changes cannot account for the majority of factor-supply changes net of both global technique changes and nontraded-output changes. Over the 1980s factor-demand shifts mandated by traded-output changes qualitatively match the effective-supply shift towards less-skilled workers. But these mandated demand changes are too small to account for all of the effective supply changes. For all five factors almost all absorption is accounted for by Israel-specific production-technique changes. During the immigration-shock period factor-demand shifts mandated by traded-output changes do not match effective-supply shifts at all: column (4) indicates a shift towards lessskilled workers, but column (3) a shift away from them. Again, the majority of absorption is accounted for by Israel-specific production-technique changes which, given the rise in the Israeli skill premium, are consistent with Israel-specific SBTC. 
In the introduction we listed many reasons--Israel's small size, openness to trade, and sizable, unexpected immigration shock — to suspect ex ante traded-output-mix adjustments. That Table 7 shows these adjustments work against relative factor supply changes reflects the limitations of the motivating Rybczynski Theorem as a comparative-static exercise. Even over short time periods, technological change like that suggested in Table 5 can swamp the effects of factorsupply shocks. To put this result in perspective, it is important to note that our analysis captures equilibrium changes in traded outputs: almost surely these output changes were driven not just by changes in factor supplies but also by changes in technology (and world prices).

\section{4c. Robustness Checks}

To help evaluate the results in Tables 5-7, we perform two robustness checks. First, we redo the decompositions using two labor categories instead of four, combining high-school graduates with those with less than high-school and college graduates with those with some college. This controls for the possibility that our initial classification creates education categories that are not comparable across countries. In particular, we are concerned about differences in when individuals complete high school and college in Israel, Russia, and the United States (see note 6). Collapsing labor into two categories partially addresses this problem.

Table 8 presents the combined decompositions in equations (3) and (6) performed on the broader labor categories; this table is structured the same as Table 5. The main findings hold for the data with broader labor categories. In both decades qualitative changes in factor supplies are not matched by qualitative changes in output mix; for most factors the contribution of production techniques to factor absorption are largely accounted for by global changes, not Israel-specific changes; and factor-supply changes net of global technique changes are very different from raw factor-supply changes. For brevity we do not report new tables parallel to Tables 6 and 7, but simply state that, as with Table 8 , the earlier findings maintain.

The second robustness check is to explore the idea that Israel absorbed global SBTC with some time lag. Again, the evidence in Figure 5 and Tables 5-7 suggests that SBTC originates in 
the United States and flows to Israel with a lag, such that during the immigration-shock period Israel seems to have experienced Israel-specific SBTC above and beyond that period's global SBTC. To check this story, we modified equation (4) by having $\hat{\mathbf{C}}^{\mathbf{U S}}$, proportionate changes in the elements of the U.S. factor-requirement matrix, be lagged rather than contemporaneous. Thus, to measure global technique changes during the immigration shock-period we calculated $\hat{\mathbf{C}}^{\text {US }}$ not using 1989-1996 data but rather 1988-1995 data, 1987-1994 data, and so forth back to the longest lag possible in our data, 1980-1987 data.

Table 9 presents the results for these lagged measures of $\hat{\mathbf{C}}^{\mathbf{U S}}$. Column (1) shows the contribution of changes in industry production techniques to changes in factor employment. In each pair of columns thereafter we decompose column (1) into portions attributable to global (i.e., U.S.) changes in industry production techniques and changes in industry production techniques that are specific to Israel, where in each pair of columns a different lag (two, four, six, or eight years) is used. Note that the first column in Table 9 is identical to its respective column in Table 5: the technology lag affects only our decomposition between global and Israel-specific production-technique changes. Table 9 provides some support for the technology-lag idea. For those with less than high school, Israel-specific technique changes are smaller for all lags, especially two-year and eight-year lags. The same is true for those with some college (except for the two-year lag). For high-school graduates and college graduates the Israel-specific technique changes are larger for all lags; for capital the results are mixed. So for two of the four labor categories, the data are consistent with the idea that global SBTC reached Israel with a time lag. More-detailed data would be required to examine this technology-lag idea more systematically.

\section{Discussion and Conclusions}

In this paper we examine two open-economy mechanisms through which Israel may have absorbed changes in labor supplies related to the Russian immigration inflow: the adoption of global changes in production technology, and national changes in the mix of traded goods produced. The first channel is motivated by the large literature documenting skill-biased technical change (SBTC) in many countries in recent decades; the second channel is based on the 
Rybczynski Theorem, a core result of Heckscher-Ohlin trade theory. To see whether these mechanisms matter, we use the production side of the Heckscher-Ohlin model to decompose how changes in factor employments are absorbed. Our main data are a panel of industry-year observations spanning all Israeli non-military GDP; to measure global technology shocks, we use data on changes in U.S. production techniques.

To briefly restate our main findings: (1) the effects of global SBTC in Israel appear to more than offset the increase in the relative supply of skilled workers due to the Russian immigration and other demographic changes; (2) changes in the output mix of traded goods contribute little to absorption of factor-supply changes in Israel; and (3) during the immigration shock Israelspecific changes in production techniques combined with the rising Israeli skill premium are consistent with Israel-specific SBTC but not with factor-supply-driven factor-price changes.

There are several comments worth repeating about our framework and its implementation. With our framework we cannot identify causal linkages between factor-supply changes and other events in Israel. Instead, we have tried to identify the contribution of different adjustment mechanisms to how Israel absorbed factor-supply changes. The usefulness of this approach is it helps clarify the role of openness in how a country absorbs factor-supply shocks.

Related to this, we do not consider how factor supplies may have changed endogenously in response to the Russian inflow. In particular, capital accumulation could help an economy adjust to labor-supply shocks. In response to the Russian influx, Israel may have experienced greater capital inflows from abroad and/or increased domestic investment, which may have reduced the shift in relative Israeli factor supplies. We do not explore this idea.

In implementing the decompositions we need to make certain decisions concerning the data. First, we combine employment data for Israelis, which include newly arrived Russians, with analogous data for the United States. In doing this, we delineate labor categories by years of education using the same cut points for all countries. Cross-country differences in educational systems suggest that this approach may introduce mismeasurement, but our reading of these systems indicates this approach is reasonable. Second, we assume both that changes in U.S. 
production techniques reflect global shocks to technology and that the United States and Israel respond similarly to these shocks. The first assumption is based on the international evidence of SBTC. A sufficient condition for the second assumption to be true is that there be productivityadjusted factor-price equalization between the two countries, which is at least plausible.

In closing, we note possible avenues for future research. We do not examine interactions between the Russian inflow and Israeli labor-market institutions-e.g., whether the inflow contributed to greater labor-market flexibility. We also have focused on multi-year changes, leaving aside short-run dynamics. Finally, we note our mild surprise that traded-output changes did not play a larger role in factor absorption in Israel. Israel's small size, openness to trade, and sizable, unexpected immigration shock make the country seem an ideal candidate for Rybczynski-type adjustments. Over the time horizon we study, technological change appears to be sufficiently important to overwhelm even large factor-supply shocks. Indeed, technological change itself, by shifting Israel's comparative advantage, may have had an important impact on the traded-output changes that occurred in the economy. That said, it might be interesting to examine the contribution of output adjustments to other episodes of large, sudden immigrations (e.g., Card (1990), Hunt (1992), and Carrington and Lima (1996), who find small wage responses to large immigration shocks in Miami, France, and Portugal, respectively). 


\section{References}

Acemoglu, Daron. 1999. “Patterns of Skill Premia.” NBER Working Paper No. 7018, March.

Angrist, Joshua D. 1995. "The Economic Returns to Schooling in the West Bank and the Gaza Strip." American Economic Review 85(5): 1065-1087.

Angrist, Joshua D. 1996. "Short-Run Demand for Palestinian Labor." Journal of Labor Economics 14(3): 425-453.

Artstein, Yael. 1999. "Wage Rigidity in Israel: Institutions Versus Market Forces.” Mimeograph.

Autor, David H., Lawrence F. Katz, and Alan B. Krueger. 1998. "Computing Inequality: Have Computers Changed the Labor Market?” Quarterly Journal of Economics, pp. 1169-1214.

Bank of Israel. 1959. The Economy and Agriculture of Israel. Jerusalem.

Bank of Israel. 1991. One Million Immigrants: An Absorption Program. Jerusalem: Ahva Press.

Beenstock, Michael and Jeffrey Fisher. 1997. "The Macroeconomic Effects of Immigration: Israel in the 1990s." Welwirtschaftliches Archiv 133(2): 330-358.

Beenstock, Michael and I. Ben-Menahem. 1997. "The Labor-Market Absorption of Immigrants from the Former USSR: Israel 1989-1994." International Migration.

Berman, Eli. 1999. "Sect, Subsidy, and Sacrifice: An Economist's View of Ultra-Orthodox Jews," Quarterly Journal of Economics, forthcoming.

Berman, Eli, John Bound, and Zvi Griliches. 1994. "Changes in Demand for Skilled Labor Within U.S. Manufacturing Industries." Quarterly Journal of Economics, 109, pp. 367-398.

Berman, Eli, John Bound, and Stephen Machin. 1998. "Implications of Skill-Biased Technological Change: International Evidence." Quarterly Journal of Economics November, 1245-1280.

Berman, Eli, and Stephen Machin. 1999. "Skill-Biased Technology Transfer: Evidence on the Factor Bias of Technological Change in Developing and Developed Countries," mimeograph.

Bernstein, Jeffrey R. and David E. Weinstein. 1998. "Do Endowments Predict the Location of Production? Evidence from National and International Data." NBER Working Paper No. 6815.

Borjas, George J. 1994. "The Economics of Immigration." Journal of Economic Literature 32: 1667-1717. 
Borjas, George J., Richard B. Freeman, and Lawrence F. Katz. 1997. "How Much Do Immigration and Trade Affect Labor Market Outcomes?" Brookings Papers on Economic Activity 1: 1-90.

Bound, John and George Johnson. 1992. "Changes in the Structure of Wages in the 1980s: An Evaluation of Alternative Explanations." American Economic Review: 371-392.

Brezis, Elise and Paul Krugman. 1996. "Immigration, Investment, and Real Wages." Journal of Population Economics 9(1): 83-93.

Card, David. 1990. "The Impact of the Mariel Boatlift on the Miami Labor Market." Industrial and Labor Relations Review 43 (2): 245-257.

Carrington, William and Pedro de Lima. 1996. "Large-Scale Immigration and Labor Markets: An Analysis of the Retornados and Their Impact on Portugal." Industrial and Labor Relations Review, January, pp. 330-347.

Coe, David and Elhanan Helpman. 1995. "'International R\&D Spillovers." European Economic Review 39: 859-887.

Dahan, Momi. 1999. “The Increase in Economic Inequality in Israel.” Mimeo.

Davis, Donald R., David E. Weinstein, Scott C. Bradford, and Kazushige Shimpo. 1997. "Using International and Japanese Regional Data to Determine When the Factor Abundance Theory of Trade Works." American Economic Review: 421-446.

Davis, Donald R., and David E. Weinstein. 1998. "An Account of Global Factor Trade." National Bureau of Economic Research Working Paper No. 6785.

Eckstein, Zvi, and Yoram Weiss. 1998. "The Absorption of Highly-Skilled Immigrants: Israel, 1990-1995." Mimeograph.

Ethier, Wilfred J. 1984. "Higher Dimensional Issues in Trade Theory." In Ronald W. Jones and Peter B. Kenen, eds, Handbook of International Economics Volume 1, (Amsterdam: North Holland Press), 131-184.

Friedberg, Rachel. 1997. "The Impact of Migration on the Israeli Labor Market." Mimeo.

Friedberg, Rachel. 1999. "You Can't Take it with You? Immigrant Assimilation and the Portability of Human Capital." Journal of Labor Economics, forthcoming.

Friedberg, Rachel, and Jennifer Hunt. 1995. "The Impact of Immigrants on Host Country Wages, Employment, and Growth." Journal of Economic Perspectives 9 (2): 23-44. 
Gregory, Paul R., and Janet E. Kohlhase. 1988. "The Earnings of Soviet Workers: Evidence from the Soviet Interview Project," The Review of Economics and Statistics 70: 23-35.

Hanson, Gordon H., and Matthew J. Slaughter. 2000. "Labor-Market Adjustment in Open Economies: Evidence From U.S. States." Mimeograph.

Harrigan, James. 1997. "Technology, Factor Supplies, and International Specialization: Estimating the Neoclassical Model." American Economic Review: 475-494.

Harrigan, James. 1995. "Factor Endowments and the International Location of Production: Econometric Evidence For the OECD, 1970-1985." Journal of International Economics 39: 123141.

Hunt, Jennifer. 1992. "The Impact of the 1962 Repatriates from Algeria on the French Labor Market," Industrial and Labor Relations Review, April, 45, 556-72.

Katz, Katrina. 1999. "Were There No Returns to Education in the USSR?" Labour Economics 6: 417-434.

Katz, Lawrence F. and Kevin M. Murphy. 1992. "Changes in Relative Wages, 1963-1987: Supply and Demand Factors." Quarterly Journal of Economics: 35-78.

Keller, Wolfgang. 1998. "Are International R\&D Spillovers Trade-Related?" European Economic Review 42: 1469-1481.

Machin, Stephen, and John Van Reenen. 1998. "Technology and Changes in Skill Structure: Evidence from Seven OECD Countries," Quarterly Journal of Economics 113: 1215-1244.

Murphy, Kevin M., Chin-hui Juhn, and Brooks Pierce. 1993. "Wage Inequality and the Rise in Returns to Skill." Journal of Political Economy 101: 410-442.

Nathanson, Roby and Lea Acdut. 1999. The New Workers: Wage Earners from Foreign Countries in Israel. Hakibbutz HaMeuchad.

Rybczynski, T. M. 1955. "Factor Endowments and Relative Commodity Prices." Economica 22: 336-341.

Sheidvasser, Sofia and Hugo Benitez-Silva. 1999. “The Educated Russian's Curse: Returns to Education in the Russian Federation," Yale University mimeograph.

Stolper, Wolfgang and Paul A. Samuelson. 1941. "Protection and Real Wages." Review of Economics and Statistics 9(1): 58-73.

Trefler, Daniel. 1993. "International Factor Price Differences: Leontief Was Right!" Journal of Political Economy 101(6): 961-987. 
Table 1: Educational Composition of the Labor Force in Israel, 1980-1996

\begin{tabular}{cccccc}
\hline \hline Group & Year & LTHS & HSG & SC & CG \\
\hline Russian & 1980 & 46.7 & 14.5 & 21.8 & 17.0 \\
Immigrants & 1989 & 36.0 & 18.2 & 24.9 & 21.0 \\
& 1996 & 24.8 & 14.2 & 36.5 & 24.5 \\
All Other & 1980 & 49.0 & 23.9 & 15.1 & 12.0 \\
Israeli Workers & 1989 & 35.7 & 30.9 & 18.2 & 15.1 \\
& 1996 & 26.2 & 33.8 & 21.4 & 18.6 \\
Total & 1980 & 48.9 & 23.3 & 15.6 & 12.3 \\
Labor Force & 1989 & 35.7 & 30.2 & 18.6 & 15.4 \\
& 1996 & 26.0 & 30.7 & 23.8 & 19.5 \\
\hline
\end{tabular}

Notes: Each cell reports the share of the labor force (those with a job plus those looking for work) of a given ethnic group accounted for by the factor in that cell. "LTHS" designates less than high school; "HSG" designates highschool graduates; "SC" designates those with some college; and "CG" designates college graduates and beyond.

Table 2: Returns to Education for Native Israelis, 1980-1996

\begin{tabular}{lcccc}
\hline \hline Years of Schooling & 1980 & 1990 & 1993 & 1996 \\
\hline 5 to 8 & 0.213 & 0.190 & 0.076 & 0.200 \\
& $(0.040)$ & $(0.073)$ & $(0.082)$ & $(0.082)$ \\
9 to 10 & 0.363 & 0.316 & 0.199 & 0.259 \\
& $(0.044)$ & $(0.075)$ & $(0.083)$ & $(0.083)$ \\
11 to 12 & 0.467 & 0.416 & 0.318 & 0.422 \\
& $(0.043)$ & $(0.072)$ & $(0.081)$ & $(0.081)$ \\
13 to 15 & 0.570 & 0.612 & 0.523 & 0.625 \\
& $(0.051)$ & $(0.076)$ & $(0.084)$ & $(0.084)$ \\
16 plus & 0.625 & 0.674 & 0.666 & 0.776 \\
& $(0.053)$ & $(0.079)$ & $(0.087)$ & $(0.085)$ \\
\hline
\end{tabular}

Notes: The table shows regression coefficients on schooling dummy variables for native Israelis from individual wage regressions reported in Dahan (1999), in which the dependent variable is log real wages and other independent variables include controls for experience, marital status, ethnicity, and broad occupation and industry categories of employment. The omitted schooling category from the wage regression is 0 to 4 years of education. Standard errors are in parentheses. 
Table 3: Industry Factor Intensities in Israel, 1980 and 1996

\begin{tabular}{|c|c|c|c|c|c|}
\hline Industry & Year & CG/LTHS & SC/LTHS & HSG/LTHS & Capital/LTHS \\
\hline Government & 1980 & 0.76 & 0.85 & 0.56 & 0.49 \\
\hline Chemicals & & 0.30 & 0.29 & 0.45 & 0.25 \\
\hline Transport Equipment & & 0.30 & 0.32 & 0.54 & 0.16 \\
\hline Mining & & 0.27 & 0.18 & 0.36 & 1.86 \\
\hline Electrical Equipment & & 0.26 & 0.39 & 0.59 & 0.26 \\
\hline Trade and Services & & 0.21 & 0.25 & 0.55 & 0.10 \\
\hline Paper and Printing & & 0.15 & 0.27 & 0.54 & 0.24 \\
\hline Plastics and Rubber & & 0.14 & 0.10 & 0.46 & 1.09 \\
\hline Machinery and Equipment & & 0.12 & 0.27 & 0.54 & 0.51 \\
\hline Water, Power, Transport & & 0.11 & 0.18 & 0.47 & 1.50 \\
\hline Metal Products & & 0.07 & 0.14 & 0.37 & 0.19 \\
\hline Nonmetalic Minerals & & 0.06 & 0.08 & 0.28 & 0.25 \\
\hline Basic Metals & & 0.06 & 0.09 & 0.30 & 0.29 \\
\hline Food and Beverages & & 0.06 & 0.09 & 0.25 & 0.21 \\
\hline Textiles & & 0.05 & 0.09 & 0.27 & 0.17 \\
\hline Agriculture & & 0.05 & 0.16 & 0.43 & 0.26 \\
\hline Construction & & 0.04 & 0.06 & 0.19 & 0.04 \\
\hline Leather Products & & 0.04 & 0.04 & 0.22 & 0.08 \\
\hline Wood Products & & 0.02 & 0.06 & 0.24 & 0.07 \\
\hline Government & 1996 & 2.27 & 2.00 & 1.33 & 1.19 \\
\hline Chemicals & & 0.77 & 0.96 & 1.13 & 0.92 \\
\hline Transport Equipment & & 1.02 & 1.09 & 1.24 & 1.59 \\
\hline Mining & & 0.30 & 0.23 & 0.69 & 2.96 \\
\hline Electrical Equipment & & 1.45 & 1.61 & 1.24 & 1.50 \\
\hline Trade and Services & & 0.72 & 1.01 & 1.46 & 0.23 \\
\hline Paper and Printing & & 0.52 & 0.95 & 1.19 & 0.56 \\
\hline Plastics and Rubber & & 0.40 & 1.10 & 1.06 & 3.10 \\
\hline Machinery and Equipment & & 0.78 & 0.91 & 1.14 & 0.78 \\
\hline Water, Power, Transport & & 0.33 & 0.71 & 1.33 & 3.64 \\
\hline Metal Products & & 0.34 & 0.59 & 0.89 & 0.50 \\
\hline Nonmetalic Minerals & & 0.27 & 0.40 & 0.64 & 0.67 \\
\hline Basic Metals & & 0.45 & 0.62 & 0.81 & 0.64 \\
\hline Food and Beverages & & 0.22 & 0.41 & 0.81 & 0.51 \\
\hline Textiles & & 0.20 & 0.41 & 0.65 & 0.38 \\
\hline Agriculture & & 0.10 & 0.20 & 0.43 & 0.33 \\
\hline Construction & & 0.07 & 0.13 & 0.35 & 0.04 \\
\hline Leather Products & & 0.23 & 0.23 & 0.51 & 0.17 \\
\hline Wood Products & & 0.13 & 0.23 & 0.70 & 0.13 \\
\hline
\end{tabular}

Notes: Each cell reports the employment ratio of that cell's two factors for the industry and year of that cell. Industries are ranked by relative employment of college graduates in 1980. See Table 1 for labor-type definitions. 
Table 4: Output-Mix Changes in Israel, 1980-1989 and 1989-1996

\begin{tabular}{crrrrr}
\hline \hline & \multicolumn{3}{c}{ Share of GDP } & \multicolumn{2}{c}{ Change in GDP Share } \\
Industry & 1980 & 1989 & 1996 & $1980-1989$ & $1989-1996$ \\
\hline Construction & 7.76 & 5.66 & 7.19 & -2.09 & 1.53 \\
Electrical Equipment & 4.96 & 5.07 & 6.07 & 0.12 & 1.00 \\
Nonmetallic Minerals & 0.98 & 0.72 & 1.07 & -0.26 & 0.35 \\
Plastic \& Rubber & 0.93 & 1.07 & 1.38 & 0.14 & 0.31 \\
Trade \& Services & 24.91 & 28.72 & 28.90 & 3.81 & 0.18 \\
Wood Products & 0.73 & 0.71 & 0.78 & -0.02 & 0.08 \\
Basic Metals & 0.44 & 0.29 & 0.38 & -0.15 & 0.08 \\
Mining & 0.72 & 0.67 & 0.67 & -0.05 & 0.00 \\
Leather & 0.17 & 0.18 & 0.16 & 0.01 & -0.03 \\
Chemicals & 1.92 & 2.34 & 2.30 & 0.42 & -0.04 \\
Metal Products & 3.11 & 2.86 & 2.80 & -0.25 & -0.06 \\
Machinery \& Equip. & 0.55 & 0.63 & 0.55 & 0.08 & -0.08 \\
Agriculture & 3.08 & 3.53 & 3.28 & 0.45 & -0.25 \\
Water, Power, Trans. & 10.91 & 12.35 & 12.06 & 1.44 & -0.29 \\
Paper \& Printing & 1.42 & 1.62 & 1.33 & 0.20 & -0.29 \\
Apparel \& Textiles & 2.42 & 1.80 & 1.48 & -0.62 & -0.32 \\
Transport Equipment & 2.81 & 1.68 & 1.35 & -1.13 & -0.33 \\
Food \& Beverages & 2.43 & 2.95 & 2.29 & 0.53 & -0.66 \\
Government & 29.75 & 27.14 & 25.97 & -2.61 & -1.18 \\
\hline
\end{tabular}

Notes: Columns for GDP shares report that industry's share of Israeli non-military GDP in that year. Columns for changes report level changes in GDP shares over the indicated time period. Industries are ranked by the change in GDP shares for the 1989-1996 period. 
Table 5:

Global Technology Changes and Absorption of Factor-Supply Changes in Israel, 1980-1996

\begin{tabular}{|c|c|c|c|c|c|c|c|}
\hline Time Period & Factor & $\begin{array}{r}\Delta \mathbf{V} \\
(1)\end{array}$ & $\begin{array}{r}\overline{\mathbf{C}} \Delta \mathbf{X} \\
(2)\end{array}$ & $\begin{array}{r}\Delta \mathbf{C} \overline{\mathbf{X}} \\
(3)\end{array}$ & $\begin{array}{r}\Delta \mathbf{C}_{\mathbf{G}} \overline{\mathbf{X}} \\
(4)\end{array}$ & $\begin{array}{r}\Delta \mathbf{C}_{\mathbf{I}} \overline{\mathbf{X}} \\
(5)\end{array}$ & $\begin{array}{r}\Delta \mathbf{V}-\Delta \mathbf{C}_{\mathbf{G}} \overline{\mathbf{X}} \\
(6)\end{array}$ \\
\hline \multirow[t]{5}{*}{ 1980-1989 } & LTHS & -12.67 & 2.42 & -15.08 & -18.00 & 2.92 & 5.34 \\
\hline & HSG & 6.09 & 2.30 & 3.79 & -2.46 & 6.25 & 8.55 \\
\hline & $\mathrm{SC}$ & 3.35 & 0.95 & 2.40 & 1.32 & 1.08 & 2.03 \\
\hline & CG & 3.23 & 0.66 & 2.56 & 1.97 & 0.60 & 1.26 \\
\hline & $\mathrm{K}$ & 1.91 & 1.87 & 0.03 & -0.97 & 1.00 & 2.87 \\
\hline \multirow[t]{5}{*}{ 1989-1996 } & LTHS & -6.67 & 7.90 & -14.57 & -9.92 & -4.66 & 3.25 \\
\hline & HSG & -0.96 & 5.32 & -6.27 & -4.67 & -1.61 & 3.71 \\
\hline & $\mathrm{SC}$ & 4.16 & 3.62 & 0.54 & 2.37 & -1.84 & 1.78 \\
\hline & CG & 3.46 & 2.93 & 0.53 & 0.61 & -0.07 & 2.86 \\
\hline & $\mathrm{K}$ & 0.25 & 3.45 & -3.20 & -1.23 & -1.97 & 1.49 \\
\hline
\end{tabular}

Notes: This table reports results for the decomposition given by equations (3) and (6) from the text. We report results on a factor-by-factor basis for each time period. Column (1) shows the change in a given factor's share of total Israeli employment (for capital, the change is for the capital-total employment ratio); column (2) shows the contribution of changes in output to changes in factor employment; column (3) shows the contribution of changes in industry production techniques to changes in factor employment. In columns (4) and (5) we further decompose column (3) into portions attributable to "global" (i.e., U.S.) changes in industry production techniques (column (4)) and changes in industry production techniques that are specific to Israel (column (5)), as defined in equations (4) and (5) in the text. Column (6) shows the difference between columns (1) and (4). "LTHS" designates workers with less than high-school; "HSG" designates high-school graduates; "SC" designates those with some college; "CG" designates college graduates and beyond; and " $\mathrm{K}$ " designates physical capital. 
Table 6:

Traded vs. Nontraded Industries

and Absorption of Factor-Supply Changes in Israel, 1980-1996

\begin{tabular}{lcrrrrrrr}
\hline \hline Time Period & Factor & $\Delta \mathbf{V}$ & $\overline{\mathbf{C}} \boldsymbol{\Delta} \mathbf{X}^{\mathbf{T}}$ & $\Delta \mathbf{C}_{\mathbf{G}} \overline{\mathbf{X}}^{\mathbf{T}}$ & $\Delta \mathbf{C}_{\mathbf{I}} \overline{\mathbf{X}}^{\mathbf{T}}$ & $\overline{\mathbf{C}} \Delta \mathbf{X}^{\mathbf{N T}}$ & $\Delta \mathbf{C}_{\mathbf{G}} \overline{\mathbf{X}}^{\mathbf{N T}}$ & $\Delta \mathbf{C}_{\mathbf{I}} \overline{\mathbf{X}}^{\mathbf{N T}}$ \\
& & $(1)$ & $(2)$ & $(3)$ & $(4)$ & $(5)$ & $(6)$ & $(7)$ \\
\hline $1980-1989$ & LTHS & -12.67 & 0.82 & -8.31 & 1.07 & 1.60 & -9.69 & 1.85 \\
& HSG & 6.09 & 0.48 & -1.64 & 2.00 & 1.82 & -0.82 & 4.25 \\
& SC & 3.35 & 0.18 & -0.45 & 1.03 & 0.77 & 1.78 & 0.05 \\
& CG & 3.23 & 0.06 & -0.19 & 0.55 & 0.61 & 2.16 & 0.05 \\
& K & 1.91 & 0.38 & -0.96 & 1.21 & 1.49 & -0.01 & -0.21 \\
$1989-1996$ & LTHS & -6.67 & 1.52 & -4.15 & -0.60 & 6.38 & -5.76 & -4.06 \\
& HSG & -0.96 & 1.07 & -2.04 & -0.68 & 4.24 & -2.62 & -0.92 \\
& SC & 4.16 & 0.73 & -0.29 & 0.41 & 2.89 & 2.67 & -2.24 \\
& CG & 3.46 & 0.51 & -0.46 & 0.74 & 2.42 & 1.06 & -0.81 \\
& K & 0.25 & 1.14 & -0.80 & -0.31 & 2.31 & -0.44 & -1.66 \\
\hline
\end{tabular}

Notes: This table reports results for the decomposition given by equation (7) from the text. We report results on a factor-by-factor basis for each time period. Column (1) shows the change in a given factor's share of total Israeli employment (for capital, the change is for the capital-total employment ratio); column (2) shows the contribution of changes in traded output to changes in factor employment; column (3) shows the contribution of changes in "global" (i.e., U.S.) industry production techniques in tradables to changes in factor employment; column (4) shows the contribution of Israel-specific changes in industry production techniques in tradables to changes in factor employment. Columns (5) through (7) parallel columns (2) through (4), but for activity in nontraded industries. "LTHS" designates workers with less than high-school; "HSG" designates high-school graduates; "SC" designates those with some college; "CG" designates college graduates and beyond; and "K" designates physical capital. 
Table 7:

Output Mix in Tradables and Absorption of Factor-Supply Changes in Israel, 1980-1996

\begin{tabular}{|c|c|c|c|c|c|c|}
\hline Time Period & Factor & (1) & $\begin{array}{l}\Delta \mathrm{V}- \\
\overline{\mathbf{C}} \Delta \mathbf{X}^{\mathrm{NT}} \\
\end{array}$ & $\begin{array}{l}\Delta \mathbf{V} \\
-\overline{\mathbf{C}} \Delta \mathbf{X}^{\mathrm{NT}} \\
-\Delta \mathbf{C}_{\mathbf{G}} \bar{X}\end{array}$ & $\overline{\mathbf{C}} \Delta \mathbf{X}^{\mathbf{T}}$ & $\Delta \mathbf{C}_{\mathbf{I}} \overline{\mathbf{X}}$ \\
\hline \multirow[t]{5}{*}{ 1980-1989 } & LTHS & -12.67 & -14.27 & 3.73 & 0.82 & 2.92 \\
\hline & HSG & 6.09 & 4.27 & 6.73 & 0.48 & 6.25 \\
\hline & $\mathrm{SC}$ & 3.35 & 2.58 & 1.26 & 0.18 & 1.08 \\
\hline & $\mathrm{CG}$ & 3.23 & 2.62 & 0.65 & 0.06 & 0.60 \\
\hline & $\mathrm{K}$ & 1.91 & 0.42 & 1.39 & 0.38 & 1.00 \\
\hline \multirow[t]{5}{*}{ 1989-1996 } & LTHS & -6.67 & -13.05 & -3.13 & 1.52 & -4.66 \\
\hline & HSG & -0.96 & -5.20 & -0.53 & 1.07 & -1.61 \\
\hline & $\mathrm{SC}$ & 4.16 & 1.27 & -1.10 & 0.73 & -1.84 \\
\hline & $\mathrm{CG}$ & 3.46 & 1.04 & 0.43 & 0.51 & -0.07 \\
\hline & $\mathrm{K}$ & 0.25 & -2.06 & -0.83 & 1.14 & -1.97 \\
\hline
\end{tabular}

Notes: This table combines some results from Tables 5 and 6 . We report results on a factor-by-factor basis for each time period. Column (1) shows the change in a given factor's share of total Israeli employment (for capital, the change is for the capital-total employment ratio); column (2) shows the change in employment share net of changes in factor absorption by the nontraded sector; column (3) shows the change in employment share net of both changes in nontraded activity and changes in "global" (i.e., U.S.) industry production techniques; column (4) shows the contribution of changes in traded output to changes in factor employment; and column (5) shows the contribution of Israel-specific changes in industry production techniques to changes in factor employment. "LTHS" designates workers with less than high-school; "HSG" designates high-school graduates; "SC" designates those with some college; "CG" designates college graduates and beyond; and "K" designates physical capital. 
Table 8:

Global Technology Changes and Absorption of Factor-Supply Changes in Israel, 1980-1996 Two Labor Categories (High-School Graduates and Below; Beyond High School)

\begin{tabular}{|c|c|c|c|c|c|c|c|}
\hline Time Period & Factor & $\begin{array}{l}\Delta \mathbf{V} \\
(1)\end{array}$ & $\begin{array}{r}\overline{\mathbf{C}} \Delta \mathbf{X} \\
(2)\end{array}$ & $\begin{array}{r}\Delta \mathbf{C} \overline{\mathbf{X}} \\
\text { (3) }\end{array}$ & $\begin{array}{r}\Delta \mathbf{C}_{\mathbf{G}} \overline{\mathbf{X}} \\
\text { (4) }\end{array}$ & $\begin{array}{r}\Delta \mathbf{C}_{\mathbf{I}} \overline{\mathbf{X}} \\
(5)\end{array}$ & $\begin{array}{r}\Delta \mathbf{V}-\Delta \mathbf{C}_{\mathbf{G}} \overline{\mathbf{X}} \\
(6)\end{array}$ \\
\hline \multirow[t]{5}{*}{ 1980-1989 } & LTHS & -6.58 & 4.72 & -11.30 & -20.46 & 9.17 & 13.88 \\
\hline & \& HSG & & & & & & \\
\hline & $\mathrm{SC}$ & 6.58 & 1.61 & 4.97 & 3.29 & 1.68 & 3.29 \\
\hline & $\& \mathrm{CG}$ & & & & & & \\
\hline & $\mathrm{K}$ & 1.91 & 1.87 & 0.03 & -0.97 & 1.00 & 2.87 \\
\hline \multirow[t]{5}{*}{ 1989-1996 } & LTHS & -7.62 & 13.22 & -20.84 & -14.58 & -6.26 & 6.96 \\
\hline & $\&$ HSG & & & & & & \\
\hline & $\mathrm{SC}$ & 7.62 & 6.55 & 1.07 & 2.98 & -1.91 & 4.64 \\
\hline & $\& \mathrm{CG}$ & & & & & & \\
\hline & $\mathrm{K}$ & 0.25 & 3.45 & -3.20 & -1.23 & -1.97 & 1.49 \\
\hline
\end{tabular}

Notes: This table reports results for the decomposition given by equations (3) and (6) from the text. It parallels Table 5, with the change of using only two labor factors instead of four. We report results on a factor-by-factor basis for each time period. Column (1) shows the change in a given factor's share of total Israeli employment (for capital, the change is for the capital-total employment ratio); column (2) shows the contribution of changes in output to changes in factor employment; column (3) shows the contribution of changes in industry production techniques to changes in factor employment. In columns (4) and (5) we further decompose column (3) into portions attributable to "global" (i.e., U.S.) changes in industry production techniques (column (4)) and changes in industry production techniques that are specific to Israel (column (5)), as defined in equations (4) and (5) in the text. Column (6) shows the difference between columns (1) and (4). "LTHS" designates workers with less than high-school; "HSG" designates high-school graduates; "SC" designates those with some college; "CG" designates college graduates and beyond; and "K" designates physical capital. 
Table 9:

Global Technology Changes Assuming Lagged Technology Flows to Israel, 1989-1996

\begin{tabular}{|c|c|c|c|c|c|c|c|c|c|c|}
\hline \multirow[t]{2}{*}{ Time Period } & \multirow[t]{2}{*}{ Factor } & $\Delta \mathbf{C} \overline{\mathbf{X}}$ & $\begin{array}{r}\Delta \mathbf{C}_{\mathbf{G}} \overline{\mathbf{X}} \\
2-\mathrm{Yr}\end{array}$ & $\begin{array}{l}\Delta \mathbf{C}_{\mathbf{I}} \overline{\mathbf{X}} \\
\mathrm{ag}\end{array}$ & $\begin{array}{r}\Delta \mathbf{C}_{\mathbf{G}} \overline{\mathbf{X}} \\
4-\mathrm{Yr}\end{array}$ & $\begin{array}{l}\Delta \mathbf{C}_{\mathbf{I}} \overline{\mathbf{X}} \\
\mathrm{ag}\end{array}$ & $\begin{array}{r}\Delta \mathbf{C}_{\mathbf{G}} \overline{\mathbf{X}} \\
6-\mathrm{Yr}\end{array}$ & $\begin{array}{l}\Delta \mathbf{C}_{\mathbf{I}} \overline{\mathbf{X}} \\
\mathrm{ag}\end{array}$ & $\begin{array}{r}\Delta \mathbf{C}_{\mathbf{G}} \overline{\mathbf{X}} \\
8-\mathrm{Yr}\end{array}$ & $\begin{array}{l}\Delta \mathbf{C}_{\mathbf{I}} \overline{\mathbf{X}} \\
\mathrm{ag}\end{array}$ \\
\hline & & (1) & (2) & (3) & (4) & $(5)$ & (6) & (7) & (8) & (9) \\
\hline \multirow[t]{5}{*}{ 1989-1996 } & LTHS & -14.57 & -11.06 & -3.51 & -10.37 & -4.20 & -10.22 & -4.35 & -11.27 & -3.30 \\
\hline & HSG & -6.27 & -4.52 & -1.75 & -2.75 & -3.53 & -2.81 & -3.46 & -2.30 & -3.98 \\
\hline & $\mathrm{SC}$ & 0.54 & 2.86 & -2.33 & 2.20 & -1.66 & 0.93 & -0.39 & 1.00 & -0.47 \\
\hline & CG & 0.53 & 0.70 & -0.17 & 0.92 & -0.38 & 1.28 & -0.75 & 1.99 & -1.45 \\
\hline & $\mathrm{K}$ & -3.20 & -1.79 & -1.41 & -1.23 & -1.98 & -1.69 & -1.52 & -1.05 & -2.15 \\
\hline
\end{tabular}

Notes: This table reports results for the decomposition given by equation (6) from the text, modified to measure changes in "global" industry production techniques using lagged U.S. data rather than contemporaneous U.S. data. Column (1) shows the contribution of changes in industry production techniques to changes in factor employment. In each pair of columns thereafter we decompose column (1) into portions attributable to "global" (i.e., U.S.) changes in industry production techniques and changes in industry production techniques that are specific to Israel, as defined in equations (4) and (5) with the modification to equation (4) of lagging U.S. changes by the number of years indicated in the table. "LTHS" designates workers with less than high-school; "HSG" designates high-school graduates; "SC" designates those with some college; "CG" designates college graduates and beyond; and "K" designates physical capital. 


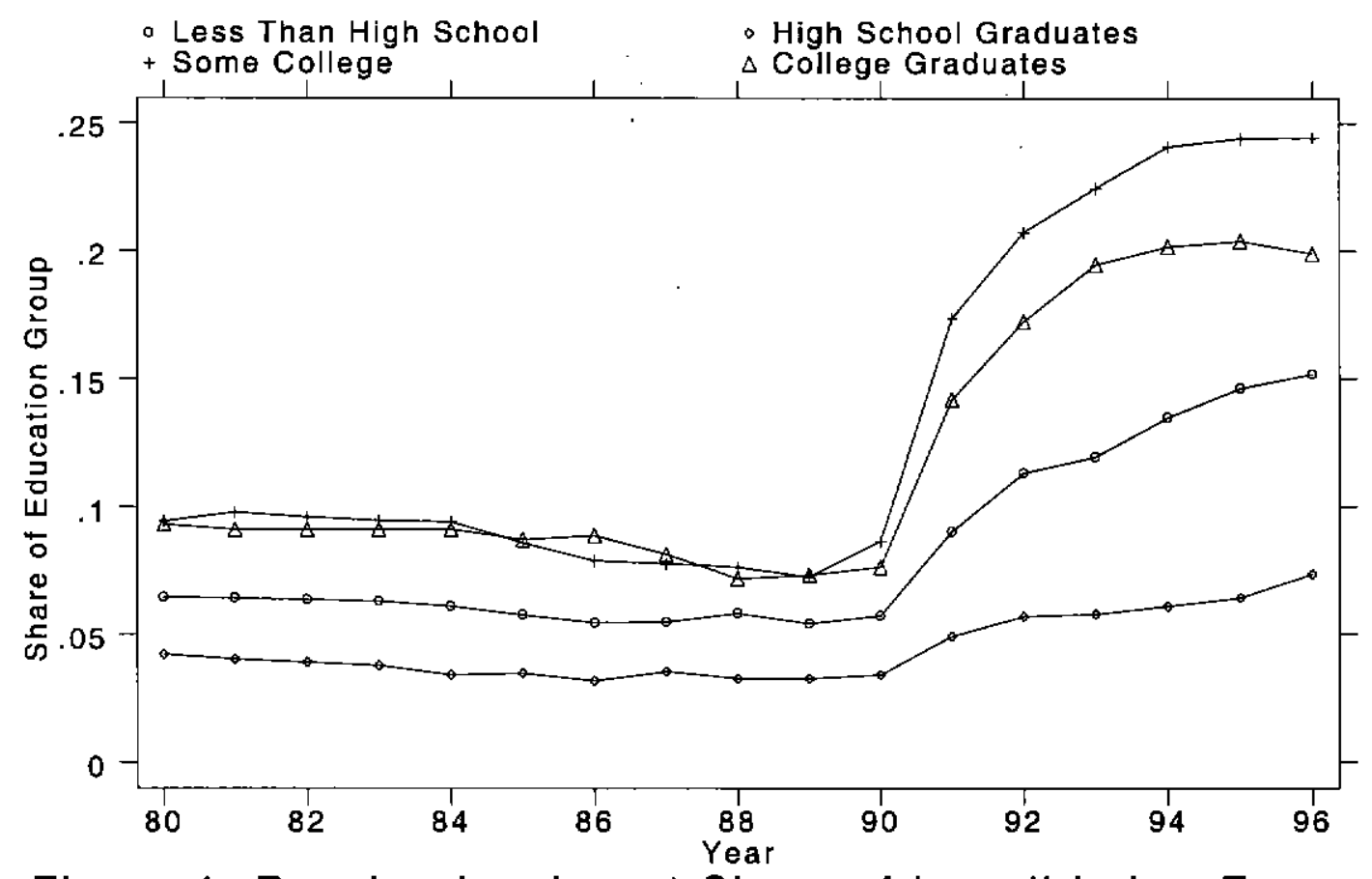

Figure 1: Russian Immigrant Share of Israeli Labor Force

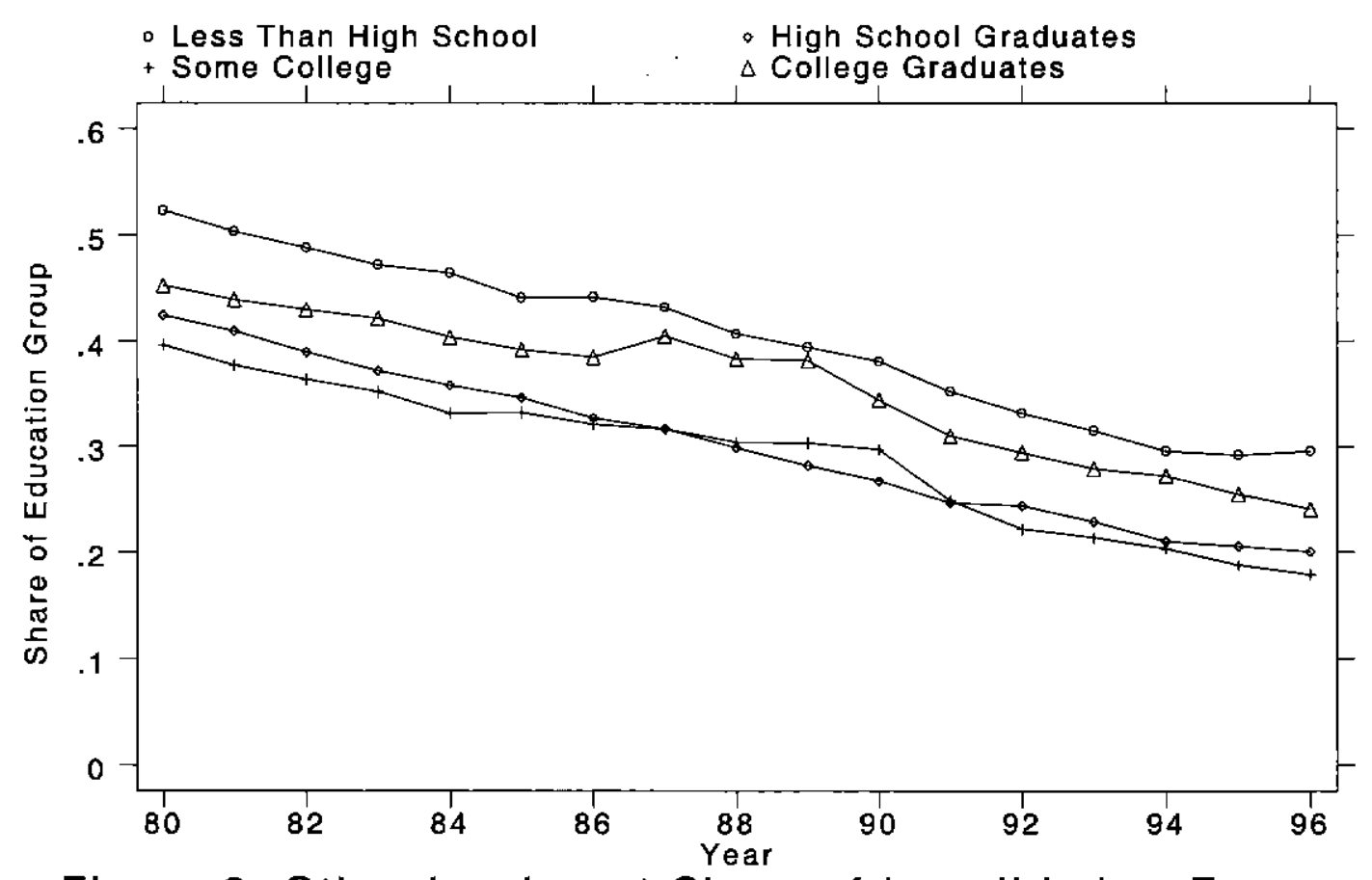

Figure 2: Other Immigrant Share of Israeli Labor Force 


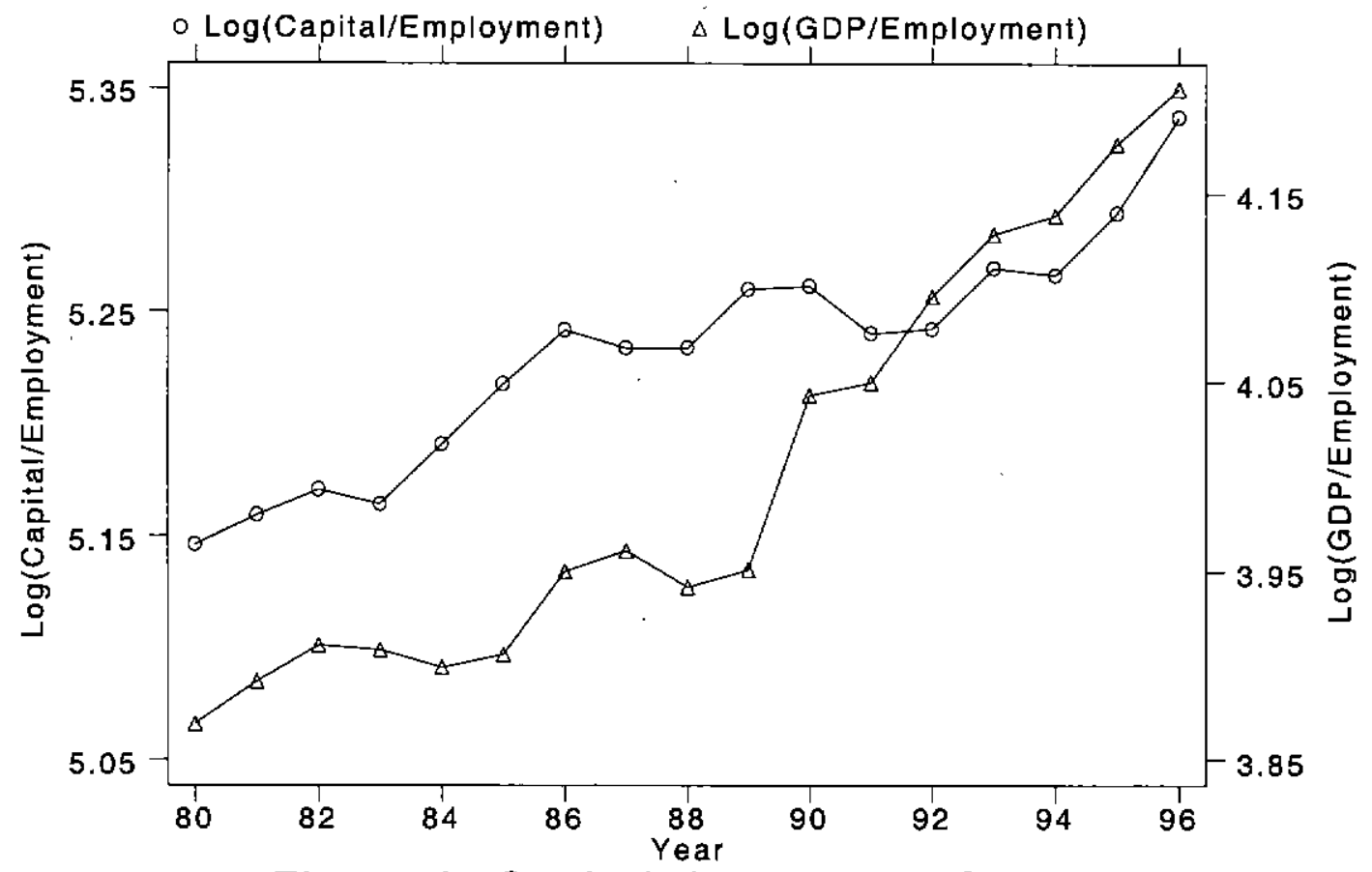

Figure 3: Capital, Labor, and Output

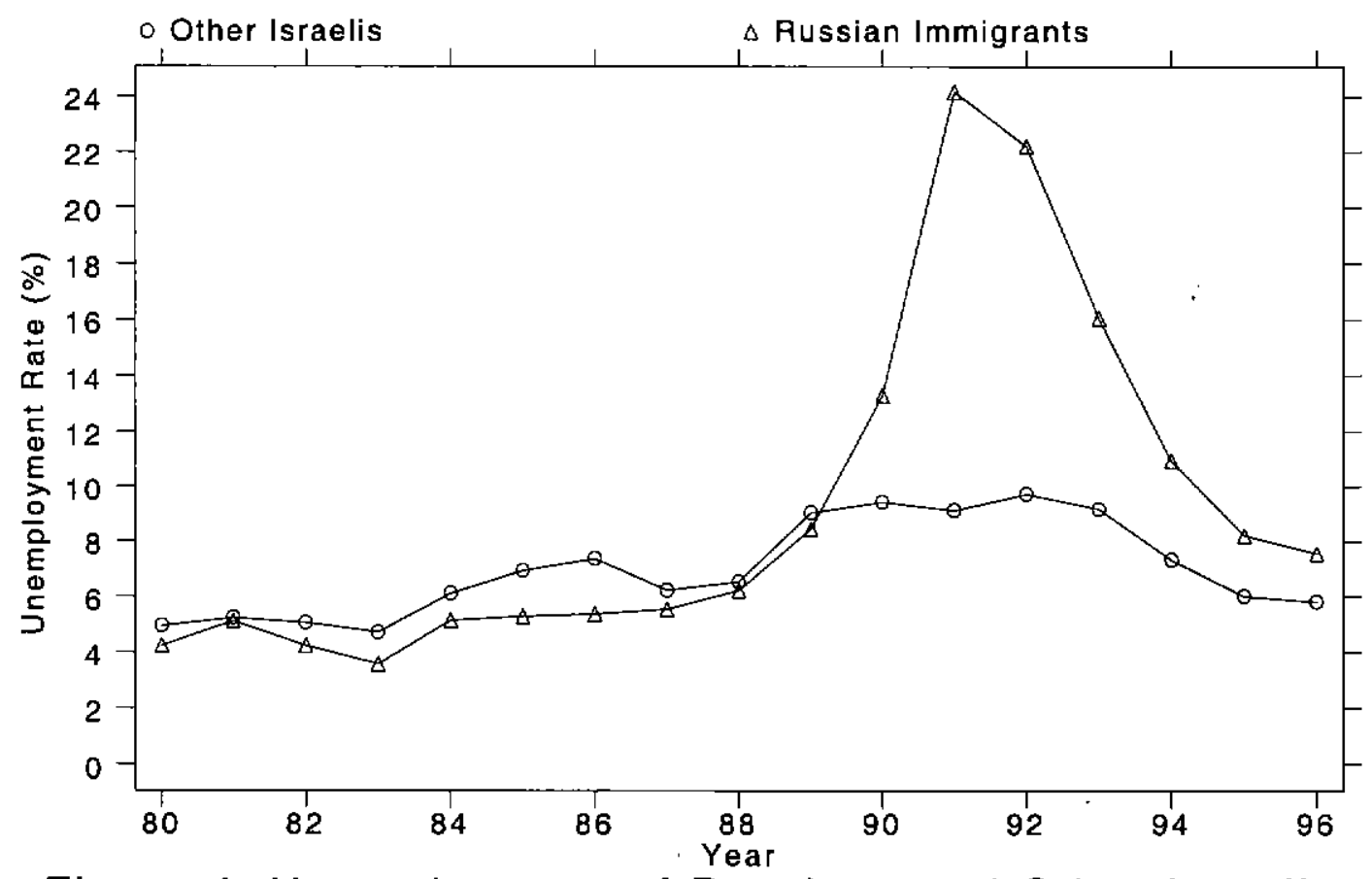

Figure 4: Unemployment of Russians and Other Israelis 


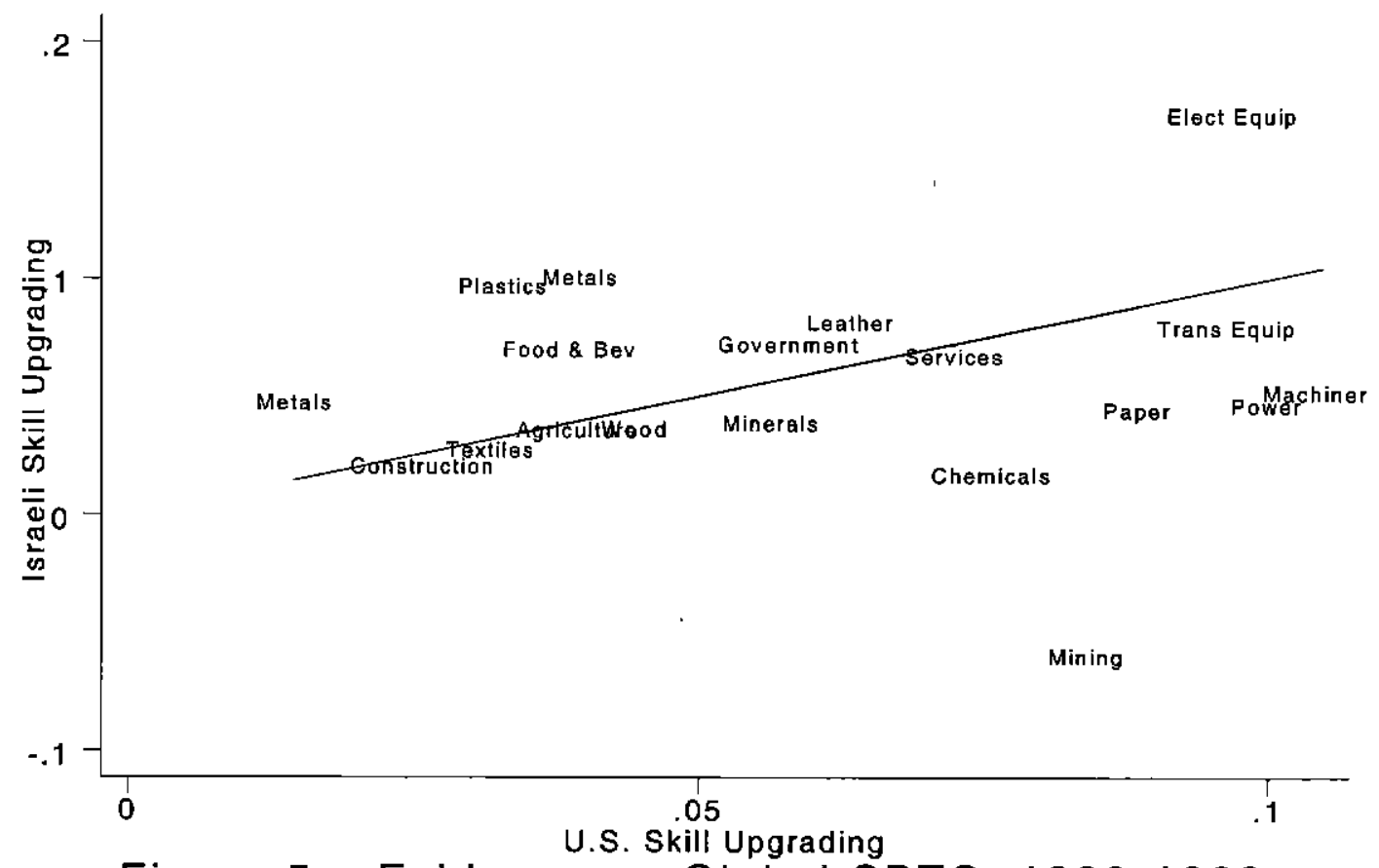

Figure 5a: Evidence on Global SBTC, 1980-1989

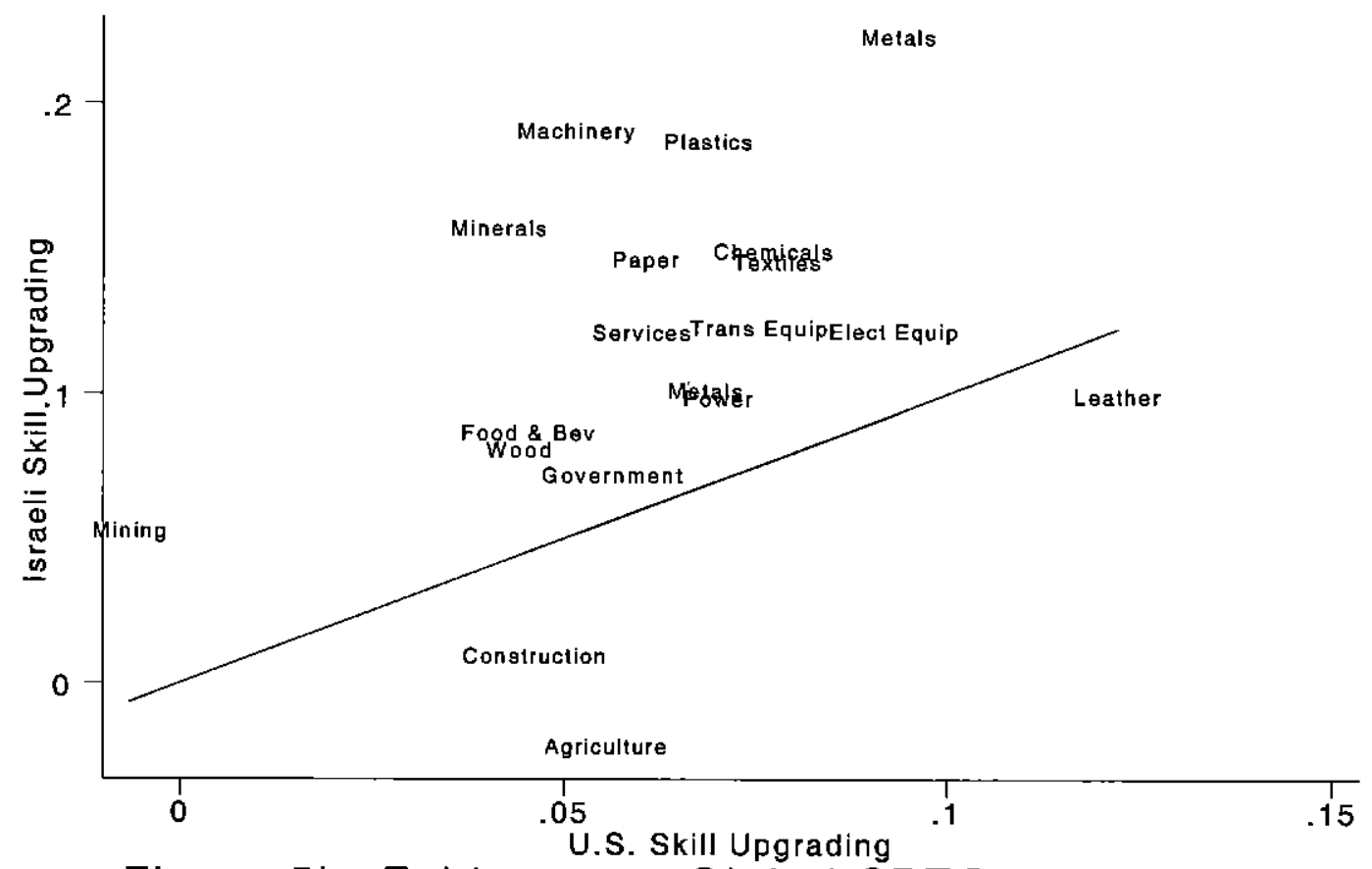

Figure 5b: Evidence on Global SBTC, 1989-1996 